\title{
ON THE ORIENTATION OF ANCIENT EGYPTIAN TEMPLES: (5) TESTING THE THEORY IN MIDDLE EGYPT AND SUDAN
}

\author{
JUAN ANTONIO BELMONTE, Instituto de Astrofísica de Canarias, \\ MAGDI FEKRI, Minufiya University, \\ YASSER A. ABDEL-HADI and MOSALAM SHALTOUT, \\ National Research Institute of Astronomy and Geophysics, Egypt, and \\ A. CESAR GONZÁLEZ GARCÍA, Universidad Autónoma de Madrid
}

In a series of papers published in this journal in recent years, some of the authors, members of the Egyptian-Spanish Mission for the Archaeoastronomy of Ancient Egypt, have made a number of interesting discoveries relating to the way in which the ancient Egyptians might have orientated their sacred buildings. ${ }^{1}$ In Paper 4, the last of the papers and an overview, a simple theory was postulated, ${ }^{2}$ according to which a series of facts were established that clearly connect temple orientation to the local landscape, landscape being understood to include both the earth and the sky. Hence simple astronomical patterns or families were basically defined in relation to the stations of the sun (solstitial, equinoctial or seasonal, notably New Year's Eve or Wepet Renpet), ${ }^{3}$ the brightest stars of the Egyptian skies (notably Sirius, ancient Egyptian Sopdet) and the cardinal directions. On several occasions, these patterns were in agreement with local topographic landmarks such as the course of the Nile. We considered our sample of 330 alignments to be statistically representative beyond doubt, and we were convinced that new data would serve only to reinforce (or slightly modify) our results. The moment has now arrived to attempt to falsify this statement.

Two experiments have been selected with this purpose. On the one hand, a new campaign, the sixth, was conducted in Egypt in December 2008 at the few temples of Middle Egypt and the Oasis of Fayum (see Figure 1) that for various reasons could not be measured in previous campaigns. ${ }^{4}$ The idea was to complete the sample of Egyptian temples almost to exhaustion. On the other hand, a completely new experiment was designed using temples in Sudan. Data were obtained from high-resolution images of Google Earth, covering a vast area of the country (but not all of it), and, in those sectors where high-resolution images were not available, from good quality maps derived from the specialist literature. The idea in this case was to carry out a significant test of our theories with a completely independent set of temples - independent not only from the geographical point of view, but also because most of them belong to an independent culture, the Kingdom of Kush, although this was admittedly heavily influenced by Egyptian schemes and traditions. ${ }^{5}$

As in previous reports, we wish to stress clearly that we are not seeking alignments of extreme precision, but we aim rather to obtain a statistically significant sample of monuments where we can perform our archaeoastronomical analysis. Bearing this is mind, we made our own fieldwork measurements using a high precision compass 


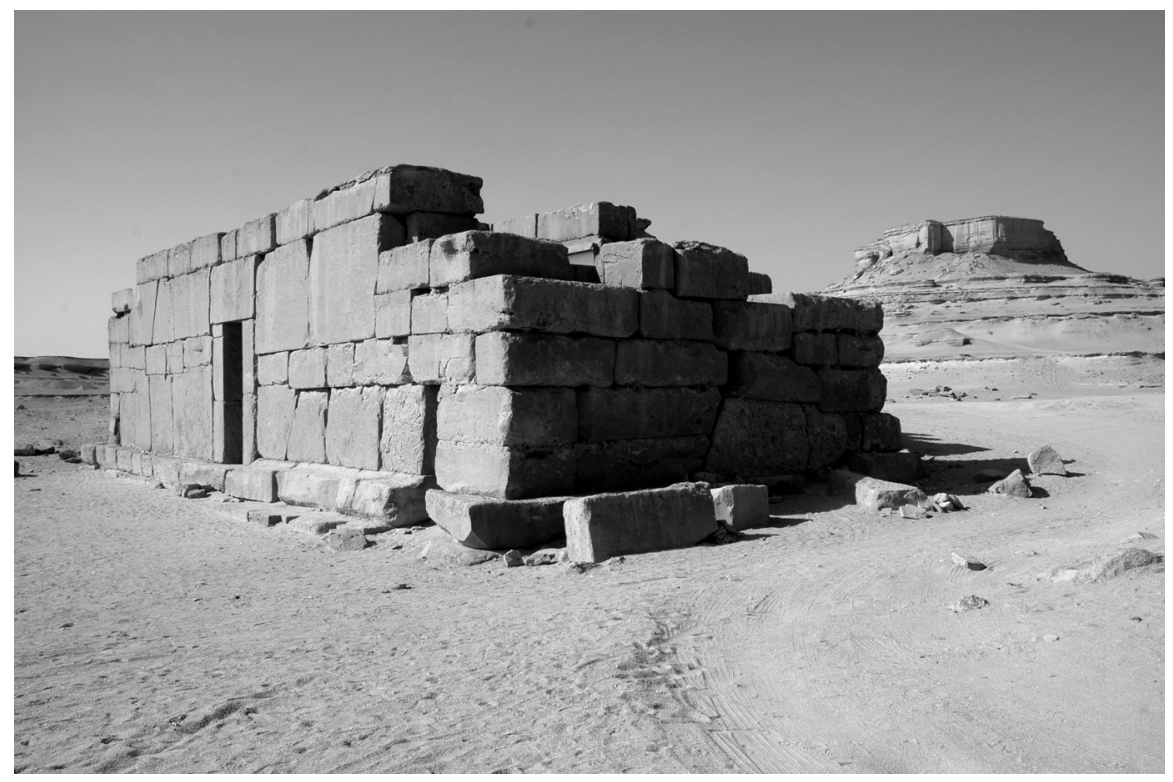

FIG. 1. The megalithic temple of Qsar al-Sagha, located in the former northern shore of Lake Moeris and now ten kilometres inland in the desert. It could have been orientated to Canopus at the moment of its construction $c .1840$ B.C. Photograph by J. A. Belmonte.

(corrected for local magnetic declination ${ }^{6}$ ) and a clinometer, either as separate instruments or enclosed within a single tandem device. The instruments permit a theoretical $\frac{10}{4}$ precision for both kinds of measurements. However, an error close to $\frac{10}{2}$ in both azimuth and angular height is probably nearer to reality. This would signify a mean error of order $\pm_{4}^{30}$ in the determination of the corresponding declination. For the latitudes of Egypt, a precision of $\frac{10}{2}$ is perhaps the best we can expect in solar or bright star observations near the horizon. These are the phenomena we will mainly discuss in this paper.

By contrast, the Sudanese data are very mixed. Measurements obtained from Google Earth images can be very precise but may suffer from an effect of parallax. As a consequence, an average error close to $1^{\circ}$ is a reasonable estimate, although in some cases a precision of $\frac{10}{2}$ may be assumed. Literature data are sparse and can range from very detailed high-quality topographic maps with a precision better than $1^{\circ}$, to general site plans where, in a couple of cases, it may be that magnetic north is indicated instead of true north. ${ }^{7}$ Hence, these data should be treated with more caution. Furthermore, neither of the two sets supplies the angular height of the horizon point. Even though within the Nile valley in Sudan we are talking mostly of flat or nearly flat areas, this is a defect that will need to be taken into account in the final result. ${ }^{8}$ 


\section{NEW DATA FROM EGYPT AND BEYOND}

Table 1 presents the data obtained in the December 2008 campaign in Middle Egypt and north Fayum, ${ }^{9}$ plus the additional data of the temple of Hathor at Timna. In this particular case, it is worth noting that the obvious importance of the course of the Nile in previous studies is not relevant since the places we visited were located far away of the Nile valley (as in Timna or Fayum), in a desert wadi as in the case of Speos Artemidos, or in a rocky outcrop overlooking the valley. Only the Thoth temple of Seikh Abada was close to the river and, as we shall see later, its course played no role in the temple's orientation. Figure 2 plots the orientation diagram of the data and, at first impression, most of the monuments can be considered to be either cardinal or within the solar arc. Hence, they respect the patterns established in previous works.

The cluster of temples excavated in the rock at Tihna el Gebel merits a special discussion. These comprise the most important sacred area of the city of Ta-Dehenet (the Cliff), the Akoris of the Greeks and Romans. The city was located where a desert wadi opens on the Nile valley between high cliffs, the southernmost crowned by a rocky outcrop where the temples are half-excavated, half-built (hemispeos). The most important buildings were those dedicated to Serapis (Osiris-Apis) and Hathor, with a shrine dedicated to Amun nearby which the Japanese team excavating the site has also interpreted as an body-embalming site. All these are orientated north, to the northern cliffs of the wadi, with varying orientations between the innermost and outermost chambers: perhaps a deliberated circumstance related to different stars in the northern skies, notably Meskhetyu. ${ }^{10}$ Additionally, the three shrines have a huge pit nearly in the main axis of the temples (see Figure 3), giving access to a set of underground chambers (a sort of catacomb) which has been interpreted as a tomb, a cenotaph or a subterranean shrine for special rituals. Interestingly, the pits of access to these three 'catacombs' show axes diverging from those of the corresponding temples but their orientations are surprisingly similar in the three cases and, within
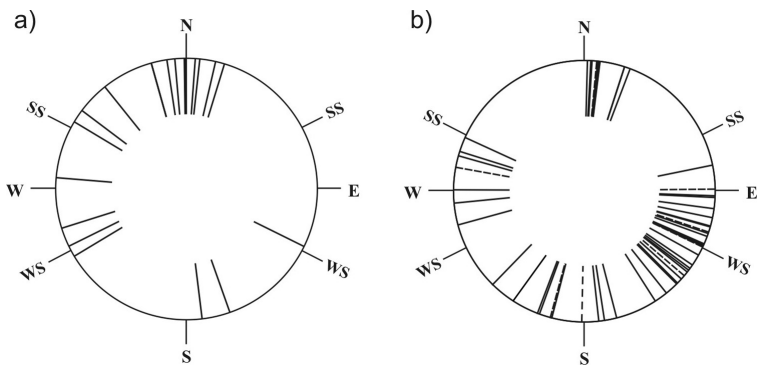

FIG. 2. Orientation diagrams of the data discussed in this paper. (a) Fieldwork data of temples in Middle Egypt and Negev. Notice the concentration in the meridian cardinal directions and the solar arc. (b) Data for Sudan as obtained from images of Google Earth (solid lines) or the literature (dashed lines). The position of the markers for summer and winter solstice (SS and WS, respectively) are settled for a latitude of $29^{\circ} \mathrm{N}$ and $18^{\circ} \mathrm{N}$ for (a) and (b), respectively. 

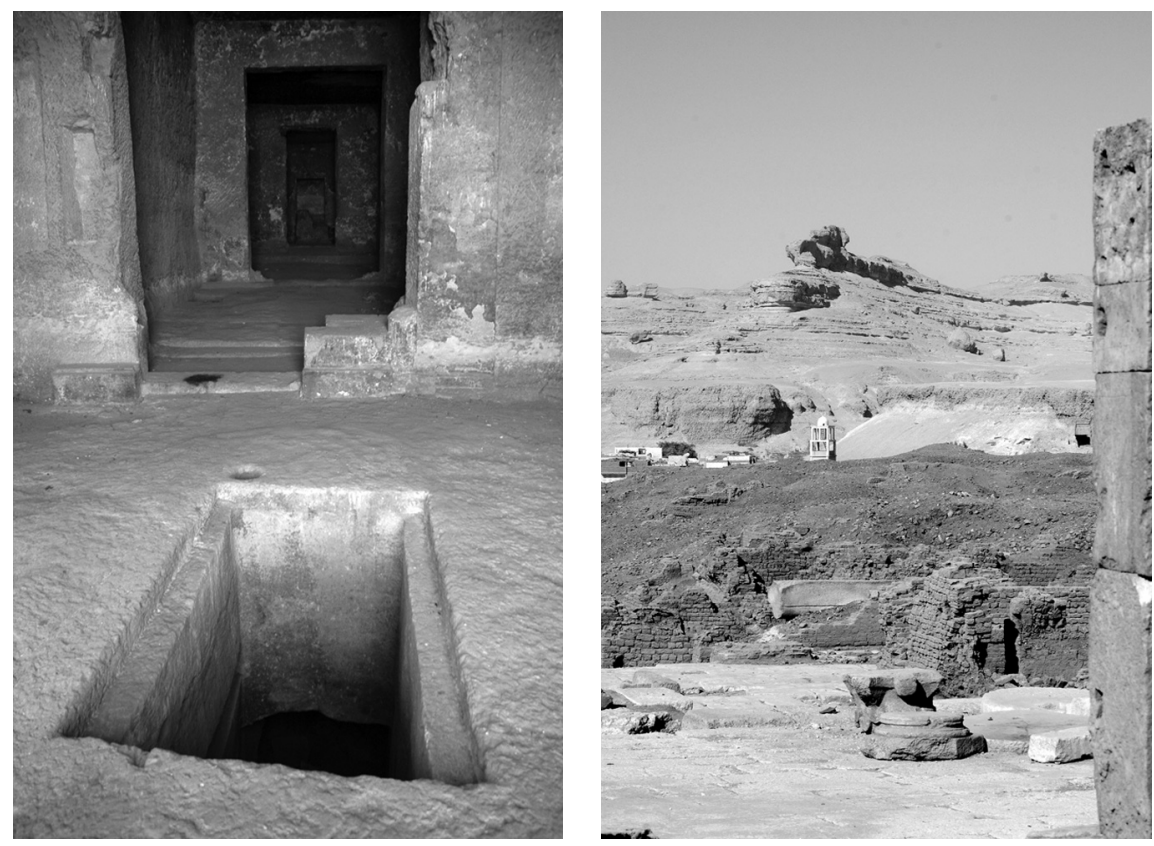

FIG. 3. (left) The interior of the hemispeos temple of Serapis at Tihna el Gebel, ancient Akoris. Notice the different orientations of the chambers in the foreground and of the close-up catacomb entrance. (right) The sphinx-like stone formation located at due north as seen from the rock temples. The extensive mudbrick-debris of the ancient ruins of Akoris can be seen in the middle of the image. Photographs by J. A. Belmonte.

the errors, can be considered due north (see Table 1).

The fascinating aspect is that this precise spot of the northern horizon is occupied by a rocky outcrop with the appearance of a sphinx with a dog's head (see Figure $3)$. The corresponding declination $\left(\sim 65^{\frac{10}{4}}\right)$ was the declination of the lowermost star of Meskhetyu, Alkaid, c. 950 B.C. In the following decades and centuries Alkaid ceased to be circumpolar, rising and setting over (or close to, as time progressed) the dog's-head, sphinx-like rocky outcrop. Around the time of Christ, other stars of this asterism, such as Merak, Phecda or Mizar, followed a similar process. We cannot be sure whether both phenomena (the presence of an underground shrine, and its orientation to the rise and setting of these stars) are related but, in view of the eschatological aspect of Meskhetyu, the hypothesis does not sound unreasonable. ${ }^{11}$ This hypothesis might be reinforced if the different rock-carved shrines in the area of Speos Artemidos are considered. Facing a high cliff in front of them, the gates of these sanctuaries are open onto the same sector of the firmament.

The temple of Hathor at Timna, built by the ancient Egyptians in the famous area known as the Pillars of Salomon and surrounded by a large network of copper mines, 
TABLE 1. Orientation of Egyptian temples and chapels as obtained in our sixth mission in December 2008. The table shows for each temple the location, the identification of the temple (either the most common name, owner deity or builder), the historical period of construction (e.g. dynasty), the latitude and longitude ( $\Phi$ and $\lambda$ ), its azimuth (a) from inside looking out, and the angular height of the horizon (h) in that direction, and the corresponding declination $(\delta)$. The last column contains additional comments or data.

\begin{tabular}{|c|c|c|c|c|c|c|c|c|}
\hline Place & Temple & Dynasty & $\Phi\left({ }^{\circ}{ }^{\prime}\right)$ & $\lambda\left(\%^{\prime \prime}\right)$ & $\mathrm{a}\left({ }^{\mathrm{o}}\right)$ & $\mathrm{h}\left({ }^{\circ}\right)$ & $\delta\left({ }^{\circ}\right)$ & Comments \\
\hline Timna & Hathor & 19th & $29 / 46$ & $34 / 58$ & 116 & $3 \frac{1}{2}$ & $-23 \frac{1}{2}$ & In Israel \\
\hline Qsar al-Sagha & Amenemhat III & 12 th & $29 / 36$ & $30 / 41$ & $160 \frac{1}{2}$ & 0 & $-55^{\frac{1}{2}}$ & \\
\hline Dimeh & Sobek & Ptolemaic & $29 / 32$ & $30 / 40$ & 173 & 0 & $-60 \frac{1}{4}$ & \\
\hline \multirow[t]{13}{*}{ Tihna el Gebel } & Osiris-Apis & Late Period & $28 / 11$ & $30 / 46$ & $351 \frac{1}{2}$ & $2 \frac{1}{2}$ & $62 \frac{3}{4}$ & Inner chambers \\
\hline & & Roman & & & $344 \frac{1}{2}$ & $0 \frac{3}{4}$ & $58 \frac{1}{2}$ & $\begin{array}{l}\text { Façade (reign of } \\
\text { Nero) }\end{array}$ \\
\hline & & & & & $359 \frac{1}{2}$ & 4 & $65 \frac{1}{2}$ & Catacomb \\
\hline & Hathor & Late Period & & & 355 & 2 & 63 & Inner chamber \\
\hline & & & & & $344 \frac{1}{2}$ & $0 \frac{1}{2}$ & $58 \frac{1}{4}$ & Hypostyle hall \\
\hline & & & & & $359 \frac{1}{2}$ & $3 \frac{3}{4}$ & $65 \frac{1}{4}$ & Catacomb \\
\hline & Amun & Graeco-Roman & & & $321 \frac{1}{2}$ & $-0 \frac{1}{2}$ & $42 \frac{3}{4}$ & \\
\hline & & & & & 360 & $3 \frac{1}{2}$ & 65 & Catacomb \\
\hline & & & & & 244 & $-0 \frac{1}{2}$ & $-23 \frac{1}{2}$ & Northern chapel \\
\hline & & & & & $252 \frac{1}{2}$ & $-0 \frac{1}{2}$ & -16 & Secondary axis \\
\hline & Sobek & Roman & & & 307 & $-0 \frac{1}{2}$ & $31 \frac{1}{4}$ & \\
\hline & Speos V & Roman? & & & 301 & $-0 \frac{1}{2}$ & $26 \frac{1}{4}$ & \\
\hline & Speos VI & Roman & & & 275 & $-0 \frac{1}{2}$ & $3 \frac{3}{4}$ & Porch in antis \\
\hline \multirow[t]{4}{*}{ Speos Artemidos } & Pakhet & 18 th & $27 / 54$ & $30 / 52$ & 13 & 17 & $73 \frac{3}{4}$ & From the gate \\
\hline & Hutmen & 18th & & & 17 & $14 \frac{1}{2}$ & $69 \frac{1}{4}$ & \\
\hline & Alexander IV & Macedonian & & & 6 & $12 \frac{1}{2}$ & $73 \frac{1}{2}$ & \\
\hline & Speos III & $?$ & & & 4 & 12 & $73 \frac{1}{2}$ & Christianized \\
\hline Seikh Abada & Thoth & 19th & $27 / 48$ & $30 / 52$ & 239 & 0 & $-27 \frac{1}{2}$ & $\left.\mathrm{~h}_{\mathrm{E}}=2 \frac{1}{4} \quad \delta=28^{\circ}\right)$ \\
\hline
\end{tabular}

is one of the remotest from their homeland. However, they nevertheless selected one of their favourite ways of orientation for the temple to the rising sun at the winter solstice. The temple itself is not constructed at the base of the 'pillars', which face roughly south, but rather at a point a hundred metres distant where the huge sandstone mountain has a small turn towards north, so permitting any structure built against it to face a suitable direction. Curiously, the Egyptian structure was later enlarged by the local Madian people, who gave the shrine a slightly different axis that violated the solar alignment.

A final interesting case is that of the temple of Thoth at Seikh Abada (see Figure 4). This New Kingdom temple is the best preserved shrine of Thoth in the area of ancient Hermopolis, the city under his patronage. Actually, it is located on the opposite side of the river where an important wadi connecting the Nile valley and the Red Sea opens to the Nile and is the precise spot where Emperor Hadrian founded the 


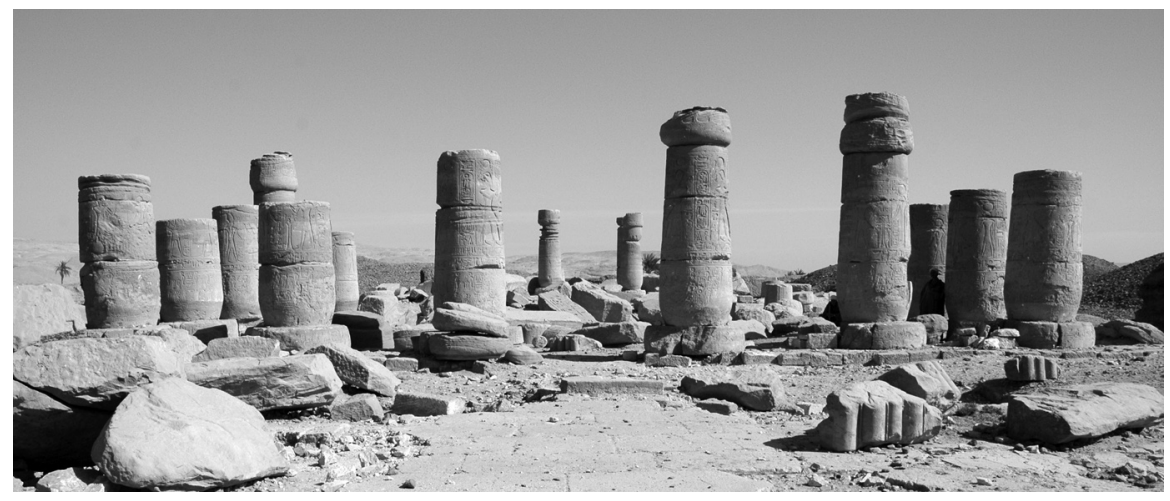

FIG. 4. The main axis of the New Kingdom temple of Thoth at Sheikh Abada (at the site of classic Antinoopolis) facing, from outside looking in, the direction on moonrise at the epoch of the major northern lunastice. Either by chance or by deliberate selection of the site, the corresponding moon also passed across the zenith. Photograph by J. A. Belmonte.

city of Antinoopolis centuries later, a town that was to become the capital of Upper Egypt for many generations. The temple axis is not perpendicular to the Nile and is almost (but not precisely) directed towards Hermopolis on the other side of the river, so local topography does not seem mandatory. However, a very interesting situation is encountered when the opposite direction (from outside looking in) is considered: the northernmost moonrise is then produced over the hills of the Eastern Desert. Furthermore, when we take into account the apparent diameter of the lunar disc, this moon would also pass across the zenith of the temple. It is fascinating to find a temple of the lunar god perhaps orientated to the northernmost rising lunar position (the lunastice) in the precise geographical area within Egypt where the same moon crosses the zenith. In our previous studies we were surprised by the lesser importance of lunar alignments in ancient Egypt. This case could be considered as the exception to the rule.

Figure 5 shows the global declination histogram for more than 350 alignments of Egyptian temples and chapels as yielded by data obtained in our six field campaigns from 2004 to 2008, during which more than 90 archaeological sites were visited. Surprisingly, or not, the histogram (thin line) is nearly identical to the one presented in earlier works (see Paper 4). The seven families of astronomical orientations are associated with ten peaks in the histogram that are located at almost exactly the same values of declination (within less than $\frac{1}{4}^{\circ}$ ) and no other peak is identified in the plot.

The new data represent only $6 \%$ of the total set of data, but a statistically significant different behaviour should still have been detected. Actually, either the KolmogorovSmirnov or the Kuiper tests applied to the data indicate that the behaviour of the two sets is in fact indistinguishable, and so our new data have served to reinforce our previous hypotheses regarding astronomical orientations of temples in ancient Egypt. It was time to perform a new completely independent experiment. 


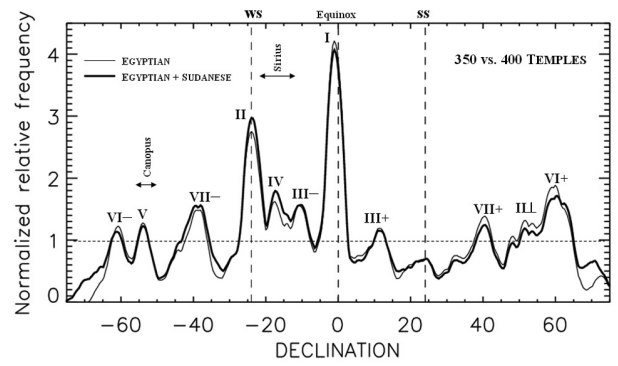

FIG. 5. Declination histogram of the complete series of temple alignment data obtained in five years of fieldwork in Egypt (thin line) versus the histogram including the data on Sudanese temples presented in this paper (thick line). Notice the striking similarities of both graphs, significantly diverging only at high absolute values of the declination as would logically be expected due to the different latitudes of the Egyptian and Sudanese samples. The extreme positions for Sirius and Canopus within all of the relevant period are clearly marked. Dashed lines for summer and winter solstices are signalled at $\pm 24^{\circ}$, respectively. See the text for further discussions.

\section{THE MONUMENTS OF THE KINGDOM OF KUSH: AN EXPERIMENT IN SUDAN}

... The excavations revealed that several times in its history the complex had been razed to the ground to be re-erected and expanded on the same spot, yet each time with a slight change of orientation ranging between $4^{\circ}$ and $5^{\circ} 20^{\prime}$. In other words, the Great Enclosure had already existed in the Napatan period. The orientation of the temples must have been determined by certain stars, whose position in the sky changed over time, and this orientation was so quintessential that the temples of the earlier complexes had to be re-erected several times. It was not dilapidation that motivated the repeated construction work, but a religious necessity to follow the stars in the orientation of the temples (Wenig, "Musawwarat es-Sufra" (ref. 17), 72).

This fascinating paragraph lays out a series of very interesting statements - the stellar orientation of Kushite monuments, reconstructions of buildings according to astronomical patterns, a close relationship with religion - that obviously needed to be tested and verified. There have been a few essays dealing with the topic of cultural astronomy and astronomical observations in the ancient Kingdom of Kush but, to our knowledge, none explicitly devoted to archaeoastronomy. From these works we learn about the presence of graffiti at Meroe suggesting the presence of astronomical instruments, presumably astronomical observations, and even the possibility of an observatory in the precinct of the ancient city. ${ }^{12}$ The encyclopaedic work of Laszlo Török even teaches us about the possible existence of an astronomer, or better, a skywatcher, among the high-ranking officers of the Kingdom of Kush. ${ }^{13}$

This was Wayekiye, son of a certain Hornakhtyotef - a prophet of Isis - who was "hont-priest of Sothis and wab-priest of the five living stars" as well as "chief 
magician of the King of Kush", as reported in an inscription on the walls of the temple of Philae dated to a period (c. A.D. 227) when the Dodecaschoenus region was under Meroitic rule. Indeed, the five living stars are the five planets visible to the naked eye and the mention of Sothis (ancient Egyptian Sopdet, i.e. Sirius, the brightest star in the sky and one of the celestial aspects of the goddess Isis) does not need further comment. Hence, we can reasonably argue that Sirius and the planets were diligently observed by a priestly caste with direct connections to the monarchy. Following our Egyptian experience and the presence in the region of celestial diagrams, ${ }^{14}$ we could even make the hypothesis that the movements of the sun, perhaps the moon, and other important stars and asterisms were also followed and studied. The idea was to test whether this knowledge could be traced in the archaeological record and, if so, how it related to what we have learnt further to the north in the land of the pharaohs.

The double kings of Kush considered themselves as heirs and alter egos of the kings of Egypt, and for a century or so, during the 25th Dynasty, they actually dominated the complete valley of the Nile from Khartoum to the Mediterranean, certainly an impressive region. Afterwards, following the Assyrian invasion, they retreated to their back-quarters behind the first or the second cataract (depending on the period) but still ruling a huge region, first from the capital city of Napata, at the foot of the "Pure Mountain", the Djebel Barkal, and later ${ }^{15}$ from the city of Meroe in the Butana region, further inland in the African continent (see Figure 6). However, the area of Napata preserved a strong religious importance and even the royal burial place was not transferred to the area of Meroe until the reign of Arqamani(qo), at the beginning of the third century B.C. ${ }^{16}$ This transfer has been taken as the reference point that normally divides the history of Kush between a Napatan and a Meroitic period.

Table 2 presents the data on Sudanese temples from the Egyptian and Kushite periods. The table distinguishes between measurements obtained directly from highresolution Google Earth images and data taken from maps or other sources in the literature. ${ }^{17}$ Early Egyptian temples (i.e. non-Kushite, mostly 18 th Dynasty) have been considered as useful data only for comparison if images from Google Earth were available, since most other temple maps are very old and difficult to verify, especially for those monuments flooded by Lake Nubia and now moved to the Khartoum Museum of Archaeology. A few recently-discovered Kushite temples for which no detailed maps exist have also been discarded in our analysis. ${ }^{18}$ The table also presents other kinds of interesting data, such as the king associated with the local inscriptions, the orientation of the Nile on site (when relevant), and the presence or otherwise within the temple of a 'dais' room. This structure basically consists of a long room with a high-place-like structure at one extreme reached by a series of stairs, and this was present in seven important temples of the Napatan and Meroitic periods. ${ }^{19}$ A longer and more substantial discussion on this important architectural feature will be found in Section 2.2.

A map of northern Sudan with the location of the sites presented in Table 2 and discussed in the text can be found in Figure 6. Most of the sites of the Napatan period are clustered in the areas of Napata and Kerma between the third and the 


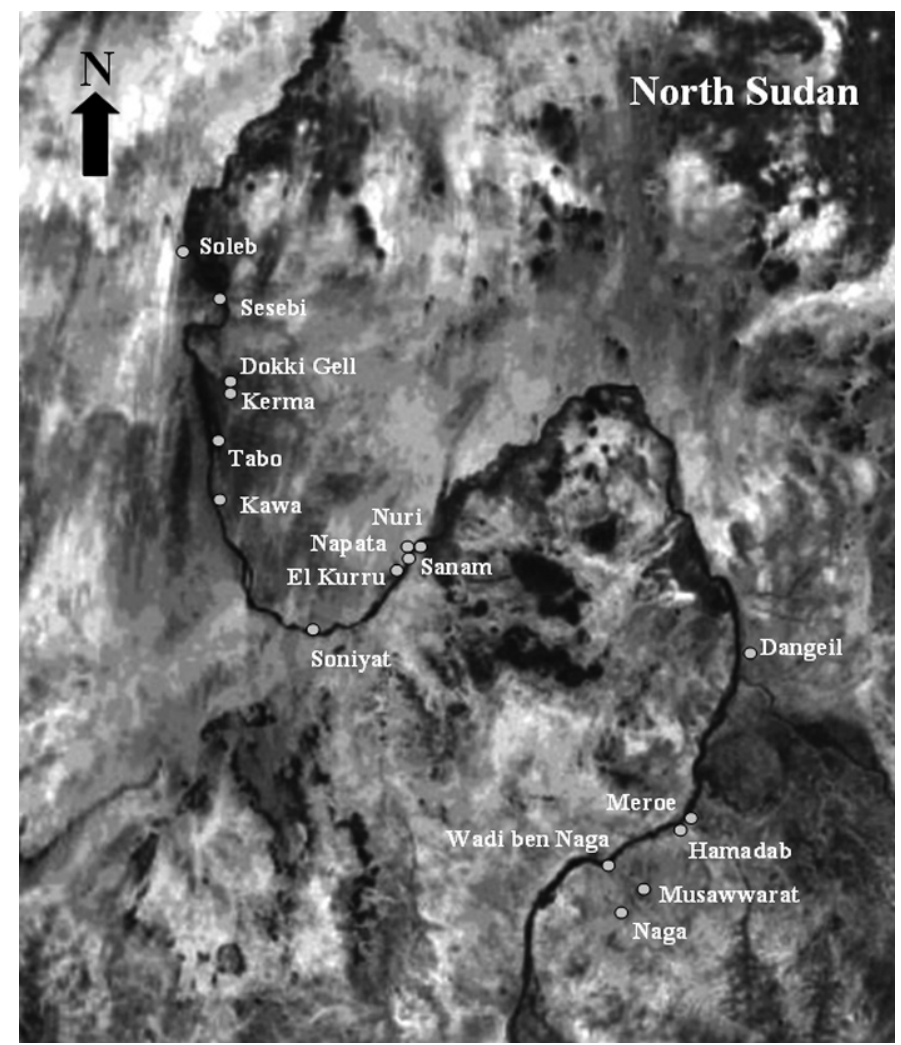

FIG. 6. Map of northern Sudan showing the location of the sites discussed in the paper where the orientation analysis experiment of Sudanese temples has been performed (see Table 2). Figure adapted from an image courtesy of Google Earth.

fourth cataracts of the Nile, while the majority of the Meroitic sites are further south, between the fifth and the sixth cataracts and inland in the region of Butana. Nevertheless, most of the Napatan sites were still in use during the Meroitic phase, and several Meroitic sites show traces of an earlier settlement during the Napatan, and even the 25th Dynasty periods. Several sites of the New Kingdom, such as Sesebi, Dokki Gel, Kawa and Napata itself, underwent reconstruction, alteration and additions, sometimes severe, during later periods. A good example is the temple of Amun (DB500) at Napata, originally built (and orientated) in the 18th Dynasty, which suffered the addition of a dais room during the reign of Peye (c. 750-712 B.C. $)^{20}$ and of two large courts during the 25 th Dynasty, with slightly different orientations (see Table 2). The curvature of the temple axis, from an original building orientated to the south-east, ${ }^{21}$ might obey ongoing attempts to accommodate the temple orientation to the local course of the Nile at $\sim 211^{\circ}$, but without much success as we must argue. 
TABLE 2. Orientation of ancient Sudanese temples as obtained from images of Google Earth and the literature (italics). ${ }^{17}$ The table shows for each temple the location, the identification of the temple (either the most common name, owner deity or builder), the historical period of construction, the latitude and longitude ( $\Phi$ and $\lambda$ ), its azimuth (a) from inside looking out, and the corresponding declination $(\delta)$. In this case angular height has been taken as $0^{\circ}$ as a first approximation. The last column contains additional comments or data (e.g. Nile course, sovereign related to the monument or a 'D' for temples with a 'dais' room). The ancient name of some Kushite settlements is given within brackets.

\begin{tabular}{|c|c|c|c|c|c|c|c|}
\hline Place & Temple & Period / Dyn. & $\Phi(\% /)$ & $\lambda(\%)$ & $\mathrm{a}\left(\left(^{\circ}\right)\right.$ & $\delta\left({ }^{\circ}\right)$ & Comments \\
\hline Soleb & Amenhotep III & 18 th & $20 / 26$ & $30 / 19$ & $78 \frac{1}{2}$ & $10 \frac{1}{2}$ & \\
\hline \multirow[t]{2}{*}{ Sesebi } & Aton & 18th & $20 / 06$ & $30 / 32$ & $92 \frac{3}{4}$ & $-2 \frac{3}{4}$ & $\mathrm{~h}=1 \frac{1 \mathrm{lo}}{2}\left(\delta=-2^{\circ}\right)$ \\
\hline & Theban Triad? & 19th & & & 92 & -2 & $\mathrm{~h}=1 \frac{1}{2} \mathrm{o}\left(\delta=-1 \frac{1 \frac{1}{2}^{\circ}}{}\right)$ \\
\hline Dokki Gel & Thutmose IV & 18th & $19 / 36$ & $30 / 24$ & 255 & $-14 \frac{1}{2}$ & "Palace" \\
\hline \multirow[t]{7}{*}{ [Pnubs] } & Thutmose IV & 18th & & & $6 \frac{1}{2}$ & $68 \frac{3}{4}$ & Main temple \\
\hline & & & & & 7 & $68 \frac{1}{2}$ & $\begin{array}{l}\text { Pylon and } \\
\text { hypostyle hall }\end{array}$ \\
\hline & Aton & 18th & & & $6 \frac{1}{2}$ & $68 \frac{3}{4}$ & \\
\hline & & & & & $97 \frac{1}{2}$ & $-7 \frac{1}{4}$ & Western chapel \\
\hline & Amun of Pnubs W & 25 th & & & $6 \frac{1}{2}$ & $68 \frac{3}{4}$ & Reconstruction \\
\hline & Amun of Pnubs E & Meroitic & & & 3 & $69 \frac{1}{2}$ & Main temple \\
\hline & & & & & $1 \frac{1}{2}$ & $69 \frac{3}{4}$ & $\begin{array}{l}\text { Pylon and } \\
\text { hypostyle hall }\end{array}$ \\
\hline \multirow[t]{3}{*}{ Kerma } & Western Dedufa & Kerma & $19 / 36$ & $30 / 25$ & $101 \frac{1}{2}$ & -11 & \\
\hline & Eastern Dedufa & Kerma & & & $165 \frac{1}{2}$ & $-66 \frac{1}{4}$ & \\
\hline & Temple KXI & Kerma & & & $173 \frac{1}{2}$ & -70 & \\
\hline \multirow[t]{2}{*}{ Tabo } & Amun & 25 th & $17 / 27$ & $30 / 26$ & 89 & $0 \frac{3}{4}$ & $\mathrm{D}$ \\
\hline & Thoth? & 18th-Meroitic & & & 6 & 69 & \\
\hline Kawa & Tutankhamun (A) & 18th & $19 / 07$ & $30 / 39$ & 18 & $63 \frac{1}{2}$ & Nile flow at $18^{\circ}$ \\
\hline \multirow[t]{3}{*}{ [Gematen] } & Amun of Gematen & 25 th & & & 288 & $16 \frac{3}{4}$ & $\begin{array}{l}\mathrm{D},-17^{\circ} \text { towards } \\
\text { East. Temple T }\end{array}$ \\
\hline & Anuket (B) & Pre 25th? & & & 18 & $63 \frac{1}{2}$ & \\
\hline & Building G1 & 25th-Napatan & & & 265 & -5 & \\
\hline Soniyat [Tergis] & Amun? & N-Meroitic & $18 / 02$ & $31 / 06$ & $209 \frac{1}{2}$ & $-56 \frac{1}{4}$ & Nile at $296^{\circ}$ \\
\hline Sanam [Krtn ?] & Amun Nubian Bull & 25 th & $18 / 31$ & $31 / 50$ & 286 & 15 & $\begin{array}{l}\mathrm{D},-15^{\frac{1}{4}} \mathrm{o} \text { towards } \\
\text { East }\end{array}$ \\
\hline \multirow{10}{*}{$\begin{array}{l}\text { Djebel Barkal } \\
\text { [Napata] }\end{array}$} & Amun (B500) & 18th & $18 / 32$ & $31 / 49$ & $134 \frac{1}{2}$ & -42 & $\mathrm{D}$, Nile at $211^{\circ}$ \\
\hline & & 25 th & & & 132 & $-39 \frac{1}{2}$ & Inner court \\
\hline & & 25 th & & & 128 & -36 & Outer court \\
\hline & B 600 & Meroitic & & & 135 & $-42 \frac{1}{4}$ & \\
\hline & Royal cult (B700) & Napatan & & & 141 & $-47 \frac{3}{4}$ & \\
\hline & B900 & Meroitic & & & 126 & -34 & \\
\hline & Amun (B800) & 25 th & & & 127 & -35 & \\
\hline & Mut (B300) & 25 th & & & 147 & -53 & Manmisi \\
\hline & Tefnut (B200) & 25 th & & & 181 & -72 & Inner chambers \\
\hline & & & & & 171 & -70 & Outer court \\
\hline Dangeil [Skaragal] & Amun & Meroitic & $18 / 08$ & $33 / 58$ & $280 \frac{1}{4}$ & $9 \frac{1}{2}$ & $\begin{array}{l}\text { D, Nile at } 28^{\circ} . \\
\text { Amanitore ( } c \text {. } \\
20 \text { A.D.) }\end{array}$ \\
\hline \multirow{7}{*}{$\begin{array}{l}\text { Begarawiya } \\
\text { [Meroe] }\end{array}$} & Amun (M260) & N-Meroitic & $16 / 56$ & $33 / 44$ & $114 \frac{1}{2}$ & $-23 \frac{1}{2}$ & $\mathrm{D}$, Nile at $25^{\circ}$ \\
\hline & KC101 & Meroitic & & & 200 & $-64 \frac{1}{2}$ & \\
\hline & M720 & Meroitic & & & $194 \frac{1}{2}$ & $-68 \frac{1}{4}$ & \\
\hline & $\mathrm{KC} 100$ & Meroitic & & & 201 & $-63 \frac{1}{2}$ & \\
\hline & KC104 & Meroitic & & & $20 \frac{1}{2}$ & $63 \frac{1}{4}$ & \\
\hline & E950 & Meroitic & & & 124 & $-32 \frac{1}{2}$ & \\
\hline & Isis (M600) & N-Meroitic & & & 114 & -23 & \\
\hline
\end{tabular}




\begin{tabular}{|c|c|c|c|c|c|c|c|}
\hline \multirow[t]{4}{*}{ Place } & Temple & Period / Dyn. & $\Phi\left({ }^{\circ} /{ }^{\prime}\right)$ & $\lambda(\%)$ & $\mathrm{a}\left(\left(^{\circ}\right)\right.$ & $\delta\left({ }^{\circ}\right)$ & Comments \\
\hline & Re' (M250) & N-Meroitic & & & $105 \frac{1}{2}$ & -15 & $\begin{array}{l}\text { Aspelta (c. } 593- \\
568 \text { в.с.) }\end{array}$ \\
\hline & Apedemak (M600) & Meroitic & & & $108 \frac{1}{2}$ & $-17 \frac{3}{4}$ & \\
\hline & M700 & Meroitic & & & 106 & $-15 \frac{1}{2}$ & \\
\hline Hamadab & Amun ? (H1000) & Meroitic & $16 / 51$ & $33 / 42$ & $294 \frac{1}{2}$ & $23 \frac{1}{4}$ & $\begin{array}{l}\text { Amanirenas (c. } 20 \\
\text { B.C.) }\end{array}$ \\
\hline Wadi ben Naga & WBN400 & Meroitic & $16 / 31$ & 33709 & 114 & $-23 \frac{1}{4}$ & $\begin{array}{l}\text { Amanisakheto's } \\
\text { city (c. } 1 \text { A.D.) }\end{array}$ \\
\hline [Arabam] & Amun (WBN500) & Meroitic & & & $114 \frac{1}{2}$ & $-23 \frac{1}{2}$ & \\
\hline Musawwarat & Amun (100) & N-Meroitic & $16 / 25$ & 33720 & $114 \frac{1}{2}$ & $-23 \frac{1}{2}$ & $\begin{array}{l}\text { Arnekhamani } \\
\text { (c.200 в.c.) }\end{array}$ \\
\hline \multirow[t]{3}{*}{ [Aborepe] } & Temple 200 & Meroitic & & & 108 & $-17 \frac{1}{4}$ & \\
\hline & Sebywmeker (300) & Meroitic & & & 195 & $-68 \frac{1}{4}$ & \\
\hline & Apedemak (1000) & Meroitic & & & 130 & $-38 \frac{1}{4}$ & $\begin{array}{l}\text { Arnekhamani } \\
\text { (c.200 B.c. })\end{array}$ \\
\hline Naga & Amun (N100) & Meroitic & $16 / 16$ & $33 / 16$ & $270 \frac{1}{2}$ & $0 \frac{1}{4}$ & $\begin{array}{l}\text { D, Natakamani (c. } \\
20 \text { A.D.) }\end{array}$ \\
\hline \multirow[t]{5}{*}{ [Tolkte] } & Apedemak (N300) & Meroitic & & & $119 \frac{1}{2}$ & $-28 \frac{1}{2}$ & \\
\hline & Kiosk & Meroitic & & & $113 \frac{1}{2}$ & -23 & \\
\hline & N200 & Meroitic & & & $3 \frac{1}{2}$ & $72 \frac{3}{4}$ & \\
\hline & Amun+? (N500) & Meroitic & & & $224 \frac{1}{2}$ & $-43 \frac{1}{2}$ & $\begin{array}{l}\text { Sanadakhete } \\
\text { (c. } 150 \text { B.c.) }\end{array}$ \\
\hline & N700 & Meroitic & & & 110 & $-19 \frac{1}{4}$ & \\
\hline
\end{tabular}

Figure 2(b) shows the orientation diagram of the data of Table 2. The diagram is instructive and, although there are temples orientated towards nearly all regions of the horizon (with the notable exception of NE and NW), there is a large concentration between $\mathrm{E}$ and $\mathrm{SE}$, and several temples on the meridian and the western solar arc. These are possible traces of an intended astronomical pattern, which ought to be analysed.

\subsection{Testing Families of Astronomical Orientations}

In previous studies (Papers 3 and 4) on the orientation of ancient Egyptian temples (see supra, Section 1) we have suggested the existence of a series of families of astronomical alignments as obtained from the analysis of the declination histograms, reflecting tendencies in the orientation of sacred spaces: (I) eastern or "equinoctial", (II) winter solstitial, (III) seasonal, (IV) of Sirius (Sothic), (V) of Canopus, (VI) meridian, and (VII) inter-cardinal (see Figure 5). These were often combined with Nile orientation in a crossed relationship between astronomy and topography. Declination histograms have the advantage of being independent of latitude and hence offer a direct view of astronomical interests across a wider area.

Figure 7 shows the declination histogram of 55 alignments in Sudanese temples. The analysis of the plot is really suggestive, revealing several clear significant peaks. Interestingly, all these peaks can be related to the previously established families 


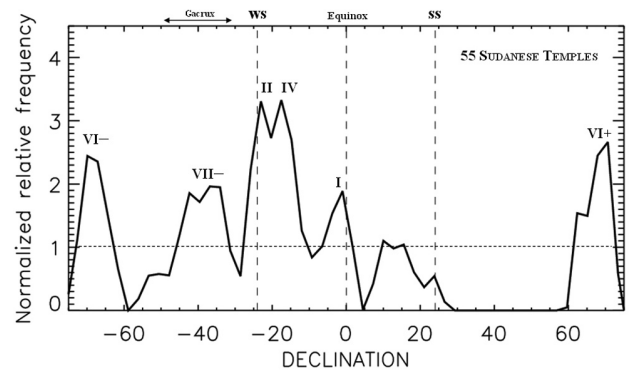

FIG. 7. Declination histogram of 55 alignments as obtained from the Sudanese temples presented in Table 2. Six peaks are clearly significant. Interestingly, all these peaks can easily find equivalences in the set of orientation families we had previously discovered for Egyptian temples. The most significant ones, with a confidence degree higher than $99 \%$, are related to the declination of the sun at the winter solstice (II) and of Sirius (IV), the brightest star of Sudanese skies. See the text for further discussions.

of orientations. The most significant is a double peak with maxima located at $-23^{\circ}$ $\pm 1^{\circ}$ and $-17 \frac{1}{2}^{\circ} \pm 1^{\circ}$. These are most probably related to the winter solstice sun and to Sirius (Sopdet), the brightest star in the Egyptian and Kushite skies (II and IV, respectively). ${ }^{22}$

On the one hand, solstitial orientations will be extensively discussed in the next section in connection with the ubiquitous Amun temples. On the other hand, the orientation to Sirius could be related to the Egyptian tradition or could even be interpreted as a local interest in this prominent star, as the titles of Wayekiye suggest. Sirius's heliacal setting and rising occurred at the latitude of Napata and the epoch of the 25th Dynasty around May 18 and June 27 (Gregorian), respectively. Considering that in the area of Kush, Nile flooding would have occurred between a fortnight and a month — depending on latitude - earlier than in Egypt, both events, but perhaps even better Sirius's heliacal setting, could have been used as clear markers of the arrival of high waters.

Following the analysis of Figure 7, we then have the accumulation peaks (VI+ and $\mathrm{VI}-$ ) representing interest in meridian $(\mathrm{N}-\mathrm{S})$ or near meridian orientations. On this occasion the peaks are centred at $+70 \frac{1}{2}$ and $-70^{\circ}$ respectively, as would be expected for the more southern latitude of the monuments under discussion $\left(20^{\circ}\right.$ to $\left.16^{\circ}\right)$. Later, a peak at $-1^{\circ} \pm 1^{\circ}$ is certainly related to 'equinoctial' orientations (I) and its discussion will also be postponed to the following section. Finally, a wide peak with a maximum between $-34^{\circ}$ and $-42^{\circ}$ could be related to the (negative) inter-cardinal family (VII-). ${ }^{23}$ The fascinating aspect of this plot is that all the significant peaks have a parallel in the northern tradition, suggesting that the strong Egyptian influence perceived in many other aspects of Kushite civilization, especially in religion, ought to be extended to orientation practices. Actually, this is not surprising since, as we have demonstrated, sacred structure orientation and religion were intimately related in ancient Egypt. 
Figure 5 (thick line) shows how the declination histogram of ancient Egyptian and Kushite shrines looks when all the corresponding temple alignments are taken into account. The diagrams with and without Kushite data are virtually identical except for the area of Family VI, which is logical considering that the complete set includes temples with much more southerly latitudes. A slight difference may be perceived for Families II and IV (more significant when Sudanese data are considered) and VII (less significant). This is certainly due to the great importance of solstitial and Sirius alignments in Kushite temples and the near-absence of (positive) inter-cardinal alignments in that particular set of data. However, there are no other peaks in the histogram that might reflect a new, independent tradition in Sudan. This result confirms what we had tentatively anticipated: the fact that new data would only slightly modify our theory, which is positively falsified within the new set.

It is now the time to analyse the quotation at the head of this section discussing the great enclosure in Musawwarat es-Sufra. According to Wening ${ }^{24}$ " the excavations revealed that several times in its history the complex had been razed to the ground to be re-erected and expanded on the same spot, yet each time with a slight change of orientation ranging between $4^{\circ}$ and $5^{\circ} 20^{\prime}$ (a total of 8 phases have been identified)". He also argues: "the orientation of the temples must have been determined by certain stars, whose position in the sky changed over time." Unfortunately we do not have direct on-site data to verify the different layouts of the various structures built on the site over time.

However, the orientation we have established for the last temples in the enclosure does not confirm Wening's ideas (see Table 2). On the one hand, the central shrine in the enclosure (MS100), possibly a temple, perhaps dedicated to Amun (see below), is orientated towards sunrise at winter solstice. The axis of the temple of Sebywmeker is apparently perpendicular to this. The winter solstice sunrise position changed by less that a quarter of a degree during the Napatan and the Meroitic periods, and consequently cannot explain differences as great as $5^{\circ}$ in the orientations. On the other hand, MS200, dedicated to an unidentified deity, is most probably orientated towards Sirius's rising, and again the minimum change of declination of this star of nearly $1^{\circ}$ due to precession for the same period cannot explain such huge azimuth variations.

It could be argued that the solstitial orientation of the shrine dominating the enclosure may be circumstantial and represents a later approach, and that the earlier layouts on site hide other star or asterism orientations. However, considering the statistical support that Figure 7 renders to winter solstitial and Sirius alignments, we considered that this opinion cannot be maintained. Perhaps the "slight" changes in the orientation were due to various successive attempts to find a satisfactory orientation for this important enclosure, only reached in the final construction phase. Actually, we agree with Wening that "this orientation — the solstitial one — was so quintessential that the temples of the earlier complexes had to be re-erected several times" until they reached the perfect demanded layout. This idea will be further supported in the following section. 
A final comment on the analysis of the data in Table 2 could be devoted to the temple of Apedemak in Naga (N300), which has an orientation close to $119 \frac{10}{2}$, yielding a declination of $-28 \frac{1}{2}$, which is, to within the errors, the southernmost declination of the moon at its southern lunastice. According to Török, ${ }^{25}$ Apedemak was a lunar god whose cult was first established in the area of Musawwarat in the 3rd century B.C. by King Arnekhamani and later diffused by his successors, and it would be tempting to establish a connection between temple ascription and orientation. However, this relationship should be considered with caution because other Apedemak temples, specifically those in Musawwarat and Meroe, do not maintain the same pattern. The absence of a lunar pattern in Egyptian temples does not help either.

\subsection{Orienting the Amun Yemples}

In a recent publication, Caroline Rocheleau ${ }^{26}$ has produced a most interesting and elucidating study on the typology of the Amun temples in ancient Nubia. This indeed includes the Amun temples of the Kushite period. Unfortunately, she devotes very little discussion to such an important structural aspect as their orientations, which, as we shall soon demonstrate, may offer important clues concerning cultural relationships, local feasts, general layout, and even chronology.

The first structure we ought to discuss is ipt swt $n$ imn npt, the temple of Amun of Napata at Djebel Barkal. First erected by Tutankhmun, its orientation has merited an individual explanation as we have already analysed. Another pre-Kushite Amun temple in the region is that of Amun of Pnubs, a site that has recently been identified with the archaeological excavations at Dokki Gel, in favour of an earlier scholarly tradition that situated it in the temple of Tabo. ${ }^{27}$ The orientation of this temple (the western on site), originally erected by Thutmose IV and later reconstructed by Akhenaten as an Aton temple and in the Napatan period (which included the 25th Dynasty), is northwards and possibly to the rising of the southernmost star of Meskhetyu of the time, Alkaid. ${ }^{28}$ Later temples kept the same alignment. When a later temple was constructed in parallel during the Meroitic period, it kept a very similar orientation and this too can be plausibly explained in a similar way (see Table 2). ${ }^{29}$ Indeed, these meridian orientations were not appropriate for a solar divinity, but we cannot be sure that this was the astral character of Amun of Pnubs and, originally, even of Amun of Napata, who was reported to reside inside the Pure Mountain of Djebel Barkal. The situation would change dramatically with the arrival of the 25th Dynasty and, especially with the reign of Taharqa (690-664 B.C.).

These two temples were known during the Napatan period as distinguished members of a group of temples situated between the third and the fourth cataracts and included in the royal coronation pilgrimage. The other two were the temple of Amun of Gematen (certainly Temple T at Kawa) and the temple of Amun Bull of Nubia at Krtn (possibly Sanam). Actually, Kawa and Sanam "were conceived with a similar complex architectural structure in mind (including the location of the dais room) and erected as a single and complete unit". ${ }^{30}$ Interestingly, both temples had nearly 


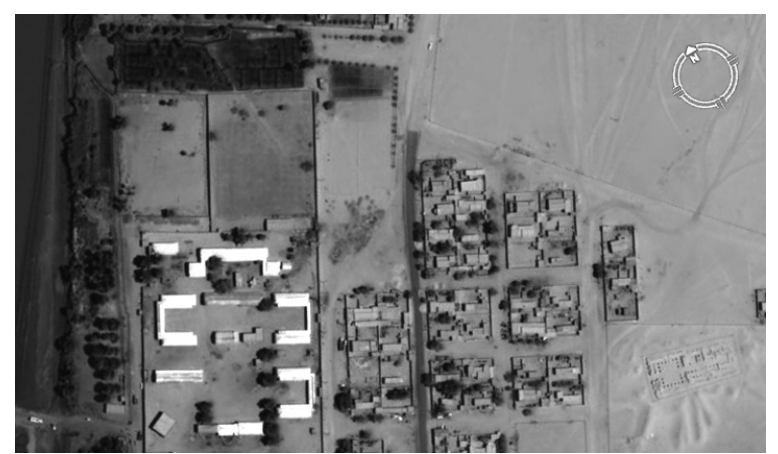

FIG. 8. The location and orientation of the Amun Bull of the Nubia temple of Sanam, in the modern village of Merowe, versus the present course of the Nile on site. Provided the Nile course has not significantly changed, temple and river were not perpendicular to each other. The plan of this temple is strikingly similar to other Amun temples, such as those in Kawa and Tabo, presumably all erected within the reign of Taharqa (690-664 B.C.), double king of Egypt and Kush. Image courtesy of Google Earth.

the same western-facing orientation, but while the temple of Amun of Gematen at Kawa (Temple T) was perpendicular to the Nile on site, the temple of Amun Bull of Nubia was not (see Figure 8). Could there be an explanation for this peculiarity? Actually, Temple $\mathrm{T}$ at Kawa was perpendicular to an earlier structure on site (Temple A), which remained abandoned on site when Taharqa decided to build the impressive Temple $\mathrm{T}$ at this barren spot on the shores of the Nile. There could have been a serious reason for that.

In earlier studies we have defended the idea that the temple of Amun at Karnak was firstly aligned towards sunrise at the winter solstice when this astronomical phenomenon was coincident with ancient Egyptian New Year's Eve or Wepet Renpet. ${ }^{31}$ Moreover, by embodying such an alignment, the temple was also perpendicular to the local course of the Nile. ${ }^{32}$ The texts have shown that the Feast of Amun of Gematen was celebrated in Kawa on I Ahket 1, commemorating the inauguration of the temple in Wepet Renpet c. 680 B.C. ${ }^{33}$ At that epoch, the declination of the sun was of the order of $-16 \frac{30}{4}$. Consequently, looking at the numbers, the temple of Amun of Gematen was orientated precisely in the same way as the temple of Amun-Re' at Karnak thirteen centuries before. This would also imply that Taharqa deliberately selected the site of Kawa because of the double astronomical and topographical alignment produced on site. Hence, Kawa imitates Karnak while Sanam possibly imitates Kawa, or vice versa. The orientation of the temple of Amun at Sanam is so similar that it can hardly be ascribed to randomness. However, its slightly different orientation may suggest a slightly earlier (c. 700 B.C.) orientation of the temple during the reign of Shabaqa, which could still be compatible with a decoration of the monument during the reign of Taharqa a couple of decades afterwards. ${ }^{34}$

It is now the time to discuss the Amun temple at Tabo. This building has an equinoctial orientation and hence fits within the solar range; located within a temporary 
island, it also faced a Nile channel to the east. This is a perfect orientation for a solar deity temple. It is our impression that this idea might support Rocheleau's hypothesis, based on structural aspects of the temple (including the possible presence of a dais room in a similar position and with a parent orientation to those of Kawa and Sanam), that the actual royal pilgrimage temple of Pnubs was that of Tabo and not the one at Dokki Gel. ${ }^{35}$ Actually, all dais rooms in Napatan and Meroitic temples are orientated in such a way that any cult-image or human body standing above the dais was facing east (this is also true for the Meroitic temples at Dangeil and Naga, which we shall shortly discuss, although the dais room is located on the northern side of these temples). There is a long-standing discussion about the real purpose of dais rooms in the temples. Hypotheses range from the place of the coronation ceremony to a sanctuary devoted to the solar cult similar to those found in Egyptian temples such as Abu Simbel. ${ }^{36}$

However, the most striking similarity for us is to the so-called "high-room of the sun" in Karnak, from where winter solstice sunrise could still have been observable in the opposite sense to the general westward orientation of the temple layout. ${ }^{37}$ Actually, we believe that the two most reasonable hypotheses should be complementary rather than in conflict with each other, in the sense that dais rooms could be coronation halls where the king, when seated or standing on the dais, could have been facing sunrise at different important moments of the yearly cycle (the equinox, Wepet Renpet or winter solstice, as we shall shortly demonstrate) depending on the temple.

The current remains on site of the Amun temple (M260) at Meroe are dated in the Meroitic period (according to the oldest evidences from the reign of Amanishakheto c. 1 A.D.) but it is normally accepted that there must have been a building on the site since the Napatan period. This sanctuary was not included in the list of coronation pilgrimage temples of the Napatan period, but this fact has been interpreted as a proof that it was already the capital of the kingdom and would indicate that it was actually a departure point for the coronation journey. This could indeed be the case after the reign of Aspelta (c. 580 B.C.) who was the king thought to have moved the capital from Napata to Meroe, although the cartouche of Senkamanisken (c. 643-623 B.C.) has also been found on site. Török has suggested that the current settling of the temple came after an extraordinary flooding that occurred in Taharqa's year 6 (685 B.C.) and that the pylons of the original temple on site faced a Nile channel and co-determined the orientation towards the rising sun. This idea is based on earlier proposals suggesting that Meroe's original location was an island. ${ }^{38}$ However, recent excavations at Meroe demonstrated that the original idea that Meroe was located on a Nile island and that the original Amun temple faced the Nile must be abandoned. Some buildings in the area have been dated as far back as 800 B.C., and the pebbles found there should be evidence of a flood and not of a dried Nile channel. Hence, the temple of Amun was probably facing the steppes of Butana from the very beginning. ${ }^{39}$

Indeed, the orientation of the Amun temple of Meroe is extraordinary. Aligned to the winter solstice sunrise and, in the opposite direction (see Table 2), perpendicular to the Nile flow on site, it strongly resembles the orientation of the parent Amun temple 
at Karnak, thus even suggesting that the site of Meroe could have been deliberately selected to fulfil the astronomical and topographical expectations required for such an important structure. The parallelism with Karnak would be completed in an extraordinary manner if we could assume that the current temple axis was firstly aligned in dates close to $c .500$ B.C. when I Akhet 1 or Wepet Renpet once more occurred in dates coincident with the winter solstice.

When dealing with a similar circumstance in the Temple $\mathrm{T}$ of Kawa, we have assumed that the Egyptian civil calendar was in standard use in the Kushite Kingdom. This could indeed be the case for the reign of the 25th Dynasty kings (including Taharqa), who were sovereigns of both Egypt and Kush. To work with our new hypothesis, we must accept that the civil calendar was adopted as the state calendar for the Kushites later on. (A further proof of this will be discussed in the following paragraphs.) The sacred precinct of Amun in Meroe was completed with a processional avenue with a series of temples flanking and nearly perpendicular to it, presumably dated in the reign of the royal couple Amanitore/Natakamani ( $c$. 20 B.C.). Also in Meroe, it has been suggested that the temple of Isis (M600) was previously dedicated to Amun - or was even the site for the earliest location of the Amun temple - during the Napatan period, a hypothesis based on the similarity of its orientation. ${ }^{40}$ However, our previous work in Egypt has shown that temples dedicated to goddesses can often have solstitial orientations, the temple of Isis at Behebit el Haggar being a perfect example. ${ }^{41}$

A most interesting case is the recently excavated temple of Amun at Dangeil, ${ }^{42}$ which faces westwards across the valley and has a dais room in its northern side, typical of the so-called Amanitore's type temples. ${ }^{43}$ However, it is not perpendicular to the Nile. With a declination of some $9 \frac{10}{2}$, it would have faced the setting sun in dates close to August 28/29 Gregorian. Interestingly, a consequence of this is that the temple could have been orientated towards Wepet Renpet c. 20 B.C., with a margin of \pm 20 years, provided the civil calendar was in use during the Meroitic period. The decoration recovered on site has shown that the temple was most probably built by King Natakamani and Queen Amanitore, so favouring a high chronology for this pair of sovereigns. ${ }^{44}$

However, there is another striking alternative. In the year 25 B.C., under the government of Emperor Augustus, Egypt adopted the Alexandrian calendar as a fixed, non-wandering calendar that included leap years. The new era adopted August 29 Julian as the fixed date for I Akhet 1 for the years to come. ${ }^{45}$ Consequently Amanitore's Amun temple at Dangeil could have been orientated towards Wepet Renpet for any accepted chronology of the queen, provided the Kushite Kingdom had also adopted the Augustan reform of the Egyptian calendar. So we face two alternatives, either to accept a high chronology for the period or to consider the possibility that the Kushites adopted in due time a calendar reform of their worst enemies. There is hardly any archaeological or documental evidence that favours either of these two alternatives. However, resorting to Ockham's razor, we would tend to favour the former possibility. 
Natakamani and Amanitore certainly built another Amanitore-type Amun temple at the important site of Naga, deep inside the steppes of Butana. This site is far from the Nile and the river should not command any of the local orientations. Once more, this temple is orientated towards a singular moment of the solar annual cycle, the equinox in this instance. In contrast with earlier periods of Egyptian - or Kushite — history, the equinox was already a well-known concept in the epoch. ${ }^{46}$ The dais room of both Amun temples at Dangeil and Naga face east, in the opposite direction to the temple gates, thus still following the same pattern established for the royal pilgrimage temples of the Napatan period (this is also the case for the temple of Amun at Meroe). Consequently, it has been suggested that the three southern temples would comprise a cluster of coronation pilgrimage temples for the Meroitic period. ${ }^{47}$ This possibility is indeed appealing. But we would like to stress that once all the Amun temples with a dais room have been considered, we have established the fact that (with the exception of Napata, where there was the constraint of earlier building considerations) all these temples do face an important milestone of the solar seasonal cycle or of the civil calendar - equinox, winter solstice, Wepet Renpet, or both - and the hypothetical solar aspect of the dais room is consequently reinforced. However, once more we wish to make it clear that the two possibilities, coronation or solar shrine, do not have to be incompatible.

It is now time to analyse a series of temples for which the Amun ascription has been either questioned or postulated. ${ }^{48}$ These are MS100, WBN500, N500 (see Table 2) and the isolated shrines at Hamadab and Soniyat (see Table 2). The striking similarity of the orientation of Temple MS100 at Musawwarat and Temple WBN500 at Wadi ben Naga to that of the temple of Amun at Meroe (and to Karnak for extension), and the absence of other buildings on site clearly ascribed to this god, can be considered as a clue towards a correct identification. A similar conclusion could be reached for the temple of Hamadab. Temple N500 at Naga has been identified as an Amun temple on basis of the local iconography, but in close association with an unidentified divinity which may be the reason for its anomalous orientation.

In contrast, the recently discovered temple at Soniyat has been tentatively classified on a structural basis as an Amun temple. ${ }^{49}$ However, its orientation, nearly perpendicular to the abnormal course of the Nile on site, is so divergent from the other Kushite Amun temples that we have serious doubts concerning the Amun ascription. According to Rocheleau, "this simply proves my point that multi-room temples should not automatically be equated Amun temples". Hence "some buildings might look like Amun temples and not be, as is the case with Soniyat". ${ }^{50}$ Indeed, a deep excavation of the site to recover new epigraphic material would be desirable.

To summarize, the Amun temples in Sudan provide a strong clue to the relationship between astronomical practices, associated with temple orientations, and diverse cultural aspects of Kushite civilization during both the Napatan and the Meroitic periods, and they confirm that Egyptian cultural influence had deep roots in the land of Kush. A further and final experiment will show how far these aspects could be researched. 


\subsection{Decoding Nuri?}

Nowhere in Nubia is the relationship between archaeology and landscape better substantiated than in the area of ancient Napata, where the Nile, flowing southwest, and the Pure Mountain in the right (west) bank of the river produce a suggestive image evocative of another peculiar landscape hundreds of kilometres to the north, in ancient Thebes. In his handbook of Kushite civilization, Török makes a parallelism between the cluster formed by the temples of Amun at Napata, on the right bank of the river, and Sanam and the pyramid necropolis of Nuri, on the left bank, and the cluster formed by the temple of Karnak, the temple of Amun at Medinet Habu and the Valley of the Kings, respectively. ${ }^{51}$

In the same line of argument, Thimothy Kendall, who has been excavating at Djebel Barkal for more than a decade, argues that "from the summit of Djebel Barkal, the pyramid of Taharqa - the earliest and largest in Nuri — indicate sunrise in the summer solstice and the heliacal rising of Sirius" while, "as seen from Nuri, the sun descends over Djebel Barkal at the moment of the winter solstice", complementing Török's ideas concerning astronomical relationships involving the sun at the solstices and Sirius. ${ }^{52}$ Considering the facts established in the previous sections, it was obvious that these suggestive possibilities ought to be checked.

As seen from Nuri (from Taharqa pyramid, to be precise), Djebel Barkal extends over an interval of azimuth from $250^{\circ}$ to $252 \frac{1}{2}^{\circ}$, with an average angular horizon height $\sim 1^{\circ}$. This represents an interval of declination of $-18 \frac{30}{4}$ to $-16^{\frac{1}{4}}$, respectively (see Figure 9). Hence, Kendall's ideas were wrong since from Nuri the sun at the winter solstice does set a few degrees to the south of the flat-topped mountain border and, consequently, the summer solstice sun does not rise above Nuri as seen from Djebel Barkal; Sirius's heliacal rising was even less visible in that direction, occurring dozens of degrees further south although still in approximately the same epoch of the year (June 27 Gregorian for the reign of Taharqa). However, the data showed another pair of really striking possibilities.

On the one hand, Sirius had a declination of $-18^{\circ} .3$ and $-17^{\circ} .9$ during the reigns of Tuthmose III (c. 1479 B.C.) and Tutankhamun (c. 1323 B.C.), respectively, the earlier builders identified at Napata. It had a declination of the order of $-16^{\circ} .8$ during the reign of Taharqa, $-16^{\circ} .3$ c. 300 B.C. at the end of the Napatan period, and it reached a minimum of $-15^{\circ} .8$ in the middle of the first millennium A.D. So, as a matter of fact, Sirius was always visible setting on the Pure Mountain from the site of the pyramid of Taharqa at Nuri, throughout the interval from the earlier occupation of Napata in the New Kingdom to the end of the Napatan period, including the reign of Taharqa who established the royal cemetery on the site..$^{53}$ Actually, as argued previously, Sirius's heliacal setting would be visible on Djebel Barkal at dates close to May 18 in that historical period, suggesting a relationship with the arrival of the Inundation. This fact alone could have signalled Nuri as a very important landmark in the Napatan region and might have justified Taharqa's selection of the site as his burial place. Actually, a relation between the orientation of the former royal tombs of the 25th Dynasty at 


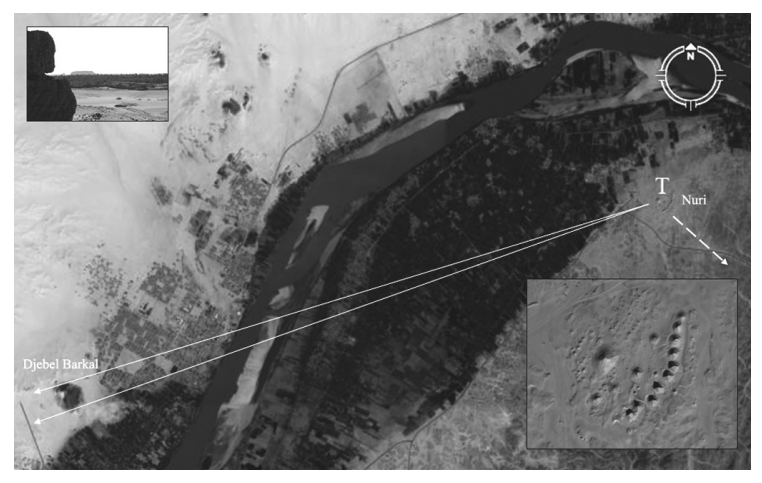

FIG. 9. Area of the region of Napata, in northern Sudan, showing the location of the pyramid cemetery of Nuri and of the sacred mountain of Djebel Barkal, on opposite sides of the Nile course. The diagram also shows the view of Djebel Barkal from the base of Taharqa's pyramid (upper-left) and a close-up satellite image of the Nuri pyramid field (bottom-right). The dash-line stands for the orientation of Taharqa pyramid (T). See the text for further discussions. Diagram of J. A. Belmonte with images courtesy of Google Earth.

El Kurru and the rising of Sirius could be suggested, as shown in Table 3. ${ }^{54}$

However, on the other hand, the site of Nuri was an even better marker for other suggestive astronomical phenomenon. Due to the wandering nature of the Egyptian civil calendar (very likely in use in Nubia during the 25th Dynasty, as we have discussed for the site of Kawa), sunset at I Akhet 1 on top of the Djebel Barkal as seen from Nuri started to occur c. 685 B.C. during the first years of the reign of Taharqa, and ended c. 648 B.C. during the reign of Atlanarsa, his son and second successor. So during most of the reign of Taharqa, sunset at Wepet Renpet occurred on the flattopped Pure Mountain as seen from his pyramid. Considering Taharqa's effort in the construction of Amon of Gematen's Temple T at Kawa, with the main axis aligned (with sunrise in this case) at the same moment of the year, we can certainly confirm the hypothesis that Taharqa's selection of Nuri as his resting place was induced by this most suggestive phenomenology, dramatically connecting his tomb to the most holy place of his homeland. The complex of problems surrounding Sirius would have indeed reinforced that decision.

Interestingly, Taharqa selected for the orientation of his pyramid one that certainly broke with his ancestors' tradition, but which was in agreement with a common tradition in the area of Thebes. Table 3 shows that his pyramid could have been orientated according to the procedures described for Family VII in Paper 4, where one of the diagonals of the pyramid base is the structural component that is more or less orientated on the meridian line at $354 \frac{1}{2}$ (see Table 3 ). The corresponding declination may have fitted the setting of either Mizar or Alioth, two of the stars of Meskhetyu. ${ }^{55}$ Figure 10 shows a preliminary orientation histogram, with data obtained from Google Earth images and the literature, of 128 royal pyramids in the 
TABle 3. Orientation of the dromos of the pyramids of 25th Dynasty rulers in El Kurru (and Nuri). All dates are B.C.

$\begin{array}{lllll}\text { Pyramid } & \mathrm{a}\left({ }^{\circ}\right) & \delta\left(^{\circ}\right) & \text { Comments } & \\ \text { Kashta }(c .770-750) & 110 & -19 & \text { Nile at 202 } & \\ \text { Peye }(c .750-712) & 108 & -17 \frac{1}{4} & & \\ \text { Shabaka }(c .712-698) & 108 \frac{1}{2} & -17 \frac{3}{4} & & \\ \text { Shabitku }(c .698-690) & 111^{\frac{1}{2}} & -20 \frac{1}{2} & & \\ \text { Taharqa }(690-664) & 129 \frac{1}{2} & -37 \frac{1}{4} & \text { (in Nuri) } 354 \frac{1}{2}^{\circ} & \rightarrow \delta \sim 70 \frac{10}{4} \\ \text { Tanwetamani }(c .664-657) & 108 \frac{1}{2} & -17 \frac{3}{4} & & \end{array}$

cemeteries of the Kushite Kingdom at El Kurru, Djebel Barkal, Nuri and Meroe. ${ }^{56}$ Although preliminary, the figure clearly shows that the Kushite pyramids concentrate in two preferred azimuth ranges, one centred at $107 \frac{10}{2}$ and the other centred at $130 \frac{3}{4}$. We could tentatively assign the first to monuments orientated towards the rising of Sirius and the second with an orientation most probably imitating the original one of the pyramid of Taharqa. ${ }^{57}$

Taharqa's successor and nephew Tanwetamani came back to El Kurru, selecting his forefather's cemetery as his resting place. However, the following king, Atlanarsa, and nineteen of his successors went back to Nuri, Nastaseñ (c. 335-315 B.C.) being the last king to build a pyramid (N15) at this burial ground. One of the mysteries of Nubian archaeology is why the Nuri pyramid field was abandoned after Nastaseñ's burial on site, first at Djebel Barkal, during a couple of decades, and definitively for Meroe c. 295 B.C. during the reign of Arkamani(qo) who inaugurated the royal cemetery at Meroe (Pyramid BrS6) ${ }^{58}$ According to Török, this abandonment was "motivated by the exhaustion of [an] appropriate place for royal burials in the elevated parts of the necropolis". ${ }^{59}$ However, considering the hypothesis that connects astronomy and

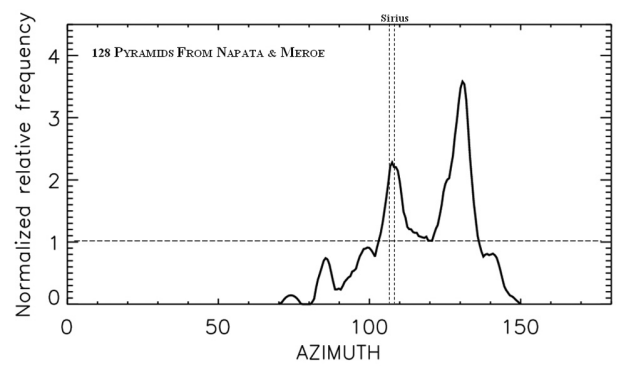

FIG. 10. Average orientation histogram of some 128 royal pyramids of the Kushite necropolises of El Kurru, Djebel Barkal, Nuri and Meroe — North and South — with data taken from the literature and images of Google Earth. This might serve as a first approximation, until the time when accurate on-site measurements become available, in the analysis of the orientation pattern of these monuments. Notice the two significant peaks at $107 \frac{1}{2}^{10}$ and $130 \frac{30}{4}$. Dashed vertical lines indicate the extreme azimuths of Sirius for the region and the corresponding period of interest. See the text for further discussion. 
landscape for the selection of Nuri as a royal burial ground during the reign of Taharqa, we may deal with a fascinating alternative for such a prosaic interpretation.

In c. 352 B.C., ${ }^{60}$ the setting sun of the wandering Wepet Renpet started once more to touch the Pure Mountain in its way north after its southern excursion of nearly three centuries. Hereafter, the I Akhet 1 sun was setting in Djebel Barkal until 315 B.C. as seen from Taharqa pyramid, exactly when the burial ground was moved to the pyramid fields near Djebel Barkal. Finally, c. 298 B.C. the setting sun of New Year's Eve stopped touching the mountain from any site on Nuri necropolis. Our suggestion is that Nuri lost its sacred character precisely because of this fact, perhaps combined with the near-simultaneous resolution of the complex of problems surrounding Sirius. During the reign of Taharqa, Nuri-Barkal's sacred geography became appealing (see Figure 9). Three and a half centuries later, the astral landscape connection reached an end and Nuri (and perhaps Djebel Barkal) lost part of its sacred aura. Hence the northern cemeteries were abandoned and the royal necropolis moved to Meroe, closing a dynamic started three centuries before with the change of capital. The Meroitic period of the Kushite civilization had definitively started.

\subsection{Concluding Remarks}

As a summary of our Sudan exercise, we might reach the conclusion that, as in the case of Egypt (see Paper 4), actually only three customs of astronomical orientations were present in the region of the ancient Kushite Kingdom throughout its land and in the course of its history: (i) cardinal, (ii) solar and (iii) stellar.

(i) The cardinal custom would be represented by Families VI, marginally I, and most likely VII, and would be achieved by the observations of certain configurations of stars in the north (predominantly, if not exclusively, stars of Meskhetyu). This procedure would initially give a near-meridian axis that would later offer various alternatives: a gate opening north, a gate opening south, a gate opening east (or west), or a new axis by turning the original by $45^{\circ}$ or $135^{\circ}$, with the gate opening near NE (or NW) or SE (or SW), respectively. ${ }^{61}$

(ii) The solar custom will be formed by Families II and I (in a few occasions) which would basically be related to important points of the solar seasonal cycle such as the winter solstice and, perhaps, the spring equinox, or in a few special cases to such an important date in the civil calendar as Wepet Renpet. Paradigmatic examples would be the Amun temples of the Napatan and Meroitic periods, notably those with a dais room.

(iii) The stellar custom would be represented by Family IV, important for both Kushite temples and pyramids. Once more, we have no doubts concerning the pertinence and relevance of the alignments to Sopdet, although new epigraphic information further confirming the importance of Sothis in the history of Kush would be highly desirable. 
It has furthermore been established that local topography could also command the orientation or even the location of sacred structures. Several temples were orientated nearly perpendicular (or parallel) to the course of the Nile and in a few cases the selection of the site may have helped to have a double topographic and astronomical alignment. In this sense, the Amun temples at Kawa and Meroe could be illustrative. In other cases, the selection of a site commanded by a solar or stellar landscape relationship has been recognized. Indeed, the case of the necropolis of Nuri is paradigmatic. Consequently, we may consider the results of our Sudanese experiment as very positive and confirming of what had previously been established for the ancient Egyptian civilization.

\section{CONCLUSIONS}

With the sixth field campaign performed in Middle Egypt and beyond in December 2008, our team has accomplished two objectives. On the one hand, we have now measured 350 alignments in temples and shrines throughout the geography of Egypt belonging to all periods of her history. This represents approximately $95 \%$ of all the temples in any state of preservation still existing in the country. Essentially only a few minor shrines in the Oasis of Kharga and a dozen temples of the Ptolemaic and Roman periods in the solitudes of the Eastern Desert are left. ${ }^{62}$ On the other hand, the new orientations presented in this paper confirm the hypotheses defended in earlier works.

For example, new suggestive examples of the solstitial family, represented by the winter solstice orientation of the temple of Hathor at Timna, and the Canopus family, such as the Middle Kingdom megalithic temple at Qsar al-Sagha, have been studied. We have also analysed a magnificent building, the temple of Thoth at Seikh Abada, which may include the first clear lunar orientation discovered in Egypt, added to the fact that it is located at the latitude where the moon marked by the alignment also crosses the zenith of the site. Actually the whole geography of the city of Thoth, Hermopolis, is within an area with a similar phenomenology and it would be worthwhile to carry out a full analysis of this possibility in the future.

However, the most fascinating results have been obtained in our analysis of Sudanese temples and shrines. A complete test of the astronomical family theory has been carried out, confirming that Kushite sacred buildings followed identical patterns of orientation to those we had previously established for ancient Egypt. These are, however, simplified since only four or five of these families are represented, but the dominant ones, solstitial (II), Sothic (IV) and meridian (VI), are highly representative and can be confirmed by local religion and tradition.

The study of the Kushite Amun temples was especially suggestive. We have shown that pilgrimage temples with a dais room have standard solar orientation either to significant milestones of the annual cycle, such as the winter solstice and, possibly, the spring equinox, or to the important date of New Year's Eve in the civil calendar, I Akhet 1 or Wepet Renpet. This suggests a continuation of Egyptian traditions 
during not only the reign of the double kings of the 25th Dynasty, notably Taharqa, but also during the Meroitic period, during the reign of the royal couple formed by Natakamani and Amanitore. Moreover, this solar aspect combined on a few occasions with local topography to create a real astronomical landscape such as the fascinating cases of Kawa and Meroe.

However, the paradigm of an astronomical landscape has been found in the area of Napata where the location of the pyramid field of Nuri with respect to the Pure Mountain of Djebel Barkal could have been deliberately selected by King Taharqa, by performing a celestial link between his burial place and the hill where the god Amun resided. This link was double, with a Sothic relationship on the one hand, but extraordinarily reinforced on the other hand by the New Year connection which happened to begin during his reign. With this idea in mind, the hypothesis of an abandonment of the Nuri necropolis when this celestial phenomenology ceased at the end of the 4 th century B.C. becomes a real and striking possibility. ${ }^{63}$

The two studies presented in this paper, in Middle Egypt and Sudan, were planned with the idea of falsifying previous ideas and hypotheses regarding the astronomical orientations of the sacred building of the ancient Egyptian civilization and, by extension, of her southern neighbour Kush. Now that the work has been concluded, we can affirm that the experiments have been a success, and that the general idea that astronomy, or sky-watching, did play a fundamental role in the culture, the religion, the architectural design and the sacred geography of the Nile Valley civilizations is certainly correct.

\section{ACKNOWLEDGEMENTS}

We wish to express our sincere acknowledgement to our colleague Dr Zahi Hawass for his strong support during these years of the Archaeoastronomy Mission as General Secretary of the Supreme Council of Antiquities. We also express our gratitude to Dr Louay Mahmoud Said and to the various inspectors, guides and escorts who have joined us during the fieldwork; they were very kind and helpful. The first author is indebted to the Egyptologist Julie Anderson for valuable discussions and for her authorization to use in this paper some of her material prior to publication. Corrections, comments and suggestions from the Egyptologists Caroline Rocheleau, José Lull and Miguel Ángel Molinero greatly enriched the paper. This work is partially financed in the framework of the projects P310793 "Arqueoastronomía" of the Instituto de Astrofísica de Canarias, and AYA2007-60213 “Orientatio ad Sidera II" of the Spanish Ministry of Science and Innovation.

\section{REFERENCES}

1. M. Shaltout and J. A. Belmonte, "On the orientation of ancient Egyptian temples: (1) Upper Egypt and Lower Nubia", Journal for the history of astronomy, xxxvi (2005), 273-98, hereafter Paper 1; J. A. Belmonte and M. Shaltout, "On the orientation of ancient Egyptian temples: (2) New experiments at the oases of the Western Desert”, ibid., xxxvii (2006), 173-92, hereafter Paper 2; 
M. Shaltout, J. A. Belmonte and M. Fekri, "On the orientation of ancient Egyptian temples: (3) Key points in Lower Egypt and Siwa Oasis", ibid., xxxviii (2007), 141-60 (Part I) and 413-42 (Part II), hereafter Paper 3; and J. A. Belmonte, M. Shaltout, and M. Fekri, "On the orientation of ancient Egyptian temples: (4) Epilogue in Serabit el Khadim and overview", ibid., xxxix (2008), 148-211, hereafter Paper 4.

2. A comprehensive summary of the theory can be found in J. A. Belmonte, M. Shaltout and M. Fekri, "Astronomy, landscape and symbolism: A study on the orientations of ancient Egyptian temples", in In search of cosmic order: Selected essays on Egyptian archaeoastronomy, ed. by J. A. Belmonte and M. Shaltout (Cairo, 2009), 213-84.

3. In our writings, we have frequently used the term 'equinoctial' for any alignment with declination near $0^{\circ}$ and 'equinox' for the corresponding time point, associated with orientations close to due east. However, this does not mean that we are attributing knowledge of the astronomical equinox (i.e. the moment when the sun crosses the celestial equator) to the ancient Egyptians or Kushites, but rather that we believe that such an orientation would be a proof of a certain interest in the four cardinal directions. Regarding orientations towards Wepet Renpet, see also J. A. Belmonte, M. Shaltout, and M. Fekri, "Astronomy and landscape in ancient Egypt: Temple alignments and implications for chronology", in Proceedings of the Xth International Conference of Egyptologists, ed. by P. Kousoulis (Orientalia Lovaniensia Analecta; Leuven, in press).

4. In September 2008, the first author had the opportunity to visit and measure the temple of Hathor at Timna, in the Negev Desert. This datum is also included in Table 1. For information on the temple, see R. H. Wilkinson, The complete temples of Ancient Egypt (London, 2000), 238.

5. Different books have analysed in detail the discrepancies, concordances and mutual influences of the ancient Egyptian and Kushite civilizations. See, for example, R. G. Morkot, The black pharaohs: Egypt's Nubian rulers (London, 2000). Excellent references for a general overview of the topic are the admirable but somewhat outdated M. Damiano-Appia, Il sogno dei faraoni neri (Florence, 1994); the complete D. A. Welsby, The Kingdom of Kush: The Napatan and Meroitic Empires (London, 1996); the detailed D. Wildung (ed.), Soudan, royaumes sur le Nil (Paris, 1997); and the recent and up-to-date D. A. Welsby and J. R. Anderson, Sudan, ancient treasures (London, 2004).

6. Once more, we should stress that magnetic anomalies are not to be expected in Egypt, where most of the terrain is limestone and sandstone. Nevertheless, the temples were mostly measured along their main axes, from inside the sanctuary to the outermost gate and, on several occasions, in the opposite direction as a check for possible alterations of the measurement.

7. Unfortunately, what kind of north is depicted was seldom reflected in archaeological plans, although the situation has improved in recent decades.

8. Actually, a certain value for the angular height can be estimated in a few cases, from high resolution maps. Indeed, we would have preferred to use our own measurements of the monuments taken on site. However, the present social and political situation in Sudan recommended caution, and the delaying of such extensive fieldwork across a variety of areas of the country until the time comes when free mobility can be guaranteed.

9. For an archaeological description of the sites, see S. Aufrère, J. C. Golvin and J. C. Goyon, L'Égypte restitueé, iii: Sites, temples et pyramides de Moyenne et Basse Égypte (Paris, 1997). R. S. Bagnall and D. W. Rathbone (eds), Egypt from Alexander to the Copts (London, 2004) is also useful.

10. For the importance of this asterism see Paper 4 and references therein, especially ref. 19. For ancient Egyptian constellations, consult J. Lull and J. A. Belmonte, "A firmament above Thebes: Uncovering the constellations of ancient Egyptians", Journal for the history of astronomy, xxxvii (2006), 373-92; or the recent, updated and enlarged J. Lull and J. A. Belmonte, "The constellations of ancient Egypt", in In search of cosmic order, ed. by Belmonte and Shaltout (ref. 2), 155-94.

11. We could even think of a relation between the sphinx-like rocky outcrop and the similar aspect of the most common images of the guardian of the underworld and the necropolises, the god Anubis. However, this idea is highly speculative and should be considered with extreme caution. 
12. "The aspect of the graffito makes it virtually certain that the instrument depicted is what was called a gnomon in antiquity", according to L. Depuydt, "Gnomons at Meroë and early trigonometry", Journal of Egyptian archaeology, lxxxiv (1998), 171-80. Depuydt also recognizes certain series of 45 strokes as possibly related to the zenith-pass of the sun at Meroe. However, according to T. J. Logan and B. Williams, "On the Meroe observatory", Beitrage zur Sudanforschung, vii (2000), 59-84, "it might be suggested that the records on the wall associate celestial events with some meteorological phenomena related to the rising of the Nile".

13. L. Török, The Kingdom of Kush: Handbook of the Napatan-Meroitic civilization (Leiden, 1997), 472. The important work of Török also presents on many occasions interesting discussions on archaeology and landscape that are relevant to our interest and which we will be discussing in this paper. The Ph.D. thesis by C. M. Rocheleau, Amon temples in Nubia: A typological study of New Kingdom, Napatan and Meroitic temples (BAR International Series, mdcccl; Oxford, 2008), is also very interesting.

14. Such as the astronomical ceiling in the burial chamber of P26 at Djebel Barkal, dated to the time of Queen Amanislo (c. 270-260 B.c.). See F. Berenguer Soto and M. Diaz de Cerio, En busca de los faraones negros (Barcelona, 2001).

15. Possibly during the reign of Aspelta (c. 580 B.C.). For a summarized recent chronology of the Kingdom of Kush within both the Napatan and the Meroitic periods, see D. N. Edwards, The Nubian past: An archaeology of the Sudan (London, 2004), 115 and 144. Török, op. cit. (ref. 13), 201-6, also offers a very detailed analysis of the series of monarchs, including chronology, burial place and complete titles among many other aspects. This analysis is generally accepted today. However, there can be great discrepancies in chronology, especially for the Meroitic period. For example, the reign of the architecturally prolific royal couple formed by King Natakamani and Queen Amanitore has been dated c. A.D. 20 by Edwards, in the mid-first century A.D. by Török, but from 12 B.C. to A.D. 12 by Damiano-Appia, op. cit. (ref. 5), 89, and from A.D. 1 to 20 by Welsby, op. cit. (ref. 5), 208-9.

16. For a brief but elucidating summary on the burial monuments of the Kings of Kush, see M. Lehner, The complete pyramids (London, 1997), 194-9.

17. Edwards, op. cit. (ref. 15), is an excellent and updated guided to the Napatan and Meroitic monuments with detailed, good quality maps of several sites. Google Earth data for Dokki Gel have been combined with the excellent maps of the site in $\mathrm{Ch}$. Bonnet and D. Valbelle, The Nubian pharaohs: Black kings of the Nile (Cairo, 2005). The important work by W. Hinkel, "L'architecture Méroïtique", in Soudan, royaumes sur le Nil, ed. by D. Wildung (Paris, 1997), 393-416, offers precise topographic maps of several sites (notably at Meroe city), and these have been cross-checked with Google Earth data in tests of their precision when possible. Consequently, Hinkel's work has been a major reference for the orientation at sites such as Wadi ben Naga and Musawwarat es-Sufra for which high resolution Google Earth images are not available. S. Wenig, "Musawwarat es-Sufra, interpreting the Great Enclosure", Sudan \& Nubia, v (2001), 71-86, has also been a reference for Musawarat. For a map of Tabo, see H. JacquetGordon, Ch. Bonnet and J. Jacquet, "Pnubs and the temple of Tabo on Argo island", Journal of Egyptian archaeology, 1x (1969), 103-11. For Hamadab, see C. L. Wolf, "Die Ansgrabungen in Hamadab bei Meroe", Der antike Sudan, xiii (2002), 92-111. Finally, a high quality map of the Amun temple at Dangeil was kindly provided by the Egyptologist Julie Anderson; see also S. Mohamed Ahmed and J. Anderson, "Le temple d'Amon à Dangeil (Soudan)", Bulletin de la Societé Française d'Égyptologie, no. 162 (2005), 10-17.

18. Such as the temples of Hugeir Gubli, Awlib, El Hassa and Alem. See, for example, Rocheleau, op. cit. (ref. 13), 31-50. In contrast, building G1 at Kawa has been identified as a temple by D. Welsby, "Kushite buildings at Kawa", www.thebritishmuseum.ac.uk/egyptian/bmsaes/welsby.html.

19. For an updated and most interesting discussion on the actual use of the dais room, see Rocheleau, op. cit. (ref. 13), 77-78. Detailed plans of the temples with dais room in Tabo, Kawa, Sanam, Napata, Dangeil, Meroe and Naga can be found in Rocheleau, op. cit. (ref. 13), 25, 28, 32, 33, 37, 38, 41 and 54, respectively. Török, op. cit. (ref. 13), 310, could also be relevant. 
20. Rocheleau, op. cit. (ref. 13), 77. The orientation of the dais room was indeed dictated by earlier constructions on site.

21 . With an azimuth of nearly $135^{\circ}$, the original 18 th Dynasty temple is a clear member of the intercardinal (VII-) family of orientations, most typical of Upper Egypt during the New Kingdom, as established in Paper 4.

22. One possibility that we might have opted for is that the latter peak could be connected to the zenith pass of the sun. The absolute value of $-17 \frac{1}{2}$ is close to the average value of the latitudes of Napata $\left(18^{\circ} 32^{\prime}\right)$ and Meroe $\left(16^{\circ} 56^{\prime}\right)$ and hence alignment to sunrise or sunset of the zenith-pass sun would have been very suggestive. This idea could be reinforced by the fact that Depuydt, op. cit. (ref. 12), following Garstang, has suggested that the counts of 45 strokes found in the graffiti of the Meroe "observatory" could be related to this local event. However, a detailed analysis of the data presented in Table 2 does not clearly favour this otherwise very suggestive possibility.

23. Most of the temples of Table 2 that may be included in this category belong to the site of Djebel Barkal. The particular topography of the Pure Mountain and the Nile course nearby could have suggested an inter-cardinal orientation for the first temple on site in the 18th Dynasty (B500 earliest phase), with its sanctuary at the base of the mountain and the entrance more-or-less facing the Nile. The other temples built on site in the following periods may have imitated this original alignment or even tried to improve the topographic approach with the turn of B500 Temple axis in the search for the Nile perpendicular. Nevertheless, Figure 7 also includes the change of declination of the northernmost star in the Crux asterism (Gacrux) in the period of interest, suggesting that a purely astronomical alignment cannot be entirely discarded. However, for the sake of simplicity, we strongly support the former option.

24. Wening, op. cit. (ref. 17), 72. In Musawwarat there are as many as seven temples, including one to Isis (MS800); however, the published maps are not detailed enough for us to have confidence in their orientations. Unfortunately, high- resolution Google Earth images do not covered this sector of the Butana. Musawwarat es-Sufra was in used from c. 500 B.C. to A.D. 350.

25. Török, op. cit. (ref. 13), 506. See also K. H. Priese, "Le monde des dieux de Méroé", in Soudan, ed. by Wildung (ref. 17), 267-9.

26. Rocheleau, op. cit. (ref. 13).

27. For Dokki Gel see Bonnet and Valbelle, op. cit. (ref. 17). For the earlier identification of Pnubs with Tabo, see Jacquet-Gordon, Bonnet and Jacquet, op. cit. (ref. 17). Rocheleau, op. cit. (ref. 13), 76-77, offers an updated most interesting discussion on the topic.

28. Merak and Phecda would also be reasonable candidates. For a general discussion on northern orientations to Meskhetyu, see Belmonte, Shaltout and Fekri, op. cit. (ref. 2) and Paper 4.

29. Alioth ceased to be circumpolar at the Napatan period and had a declination of $\sim 699_{4}^{\frac{30}{0}}$ c. 500 в.C.

30. Rocheleau, op. cit. (ref. 13), 70-71.

31. Also rendered as I Akhet 1. For a discussion on Egyptian calendrics see J. A. Belmonte, "Some open questions on the Egyptian calendar: An astronomer's view", Trabajos de Egiptología (Papers on ancient Egypt), no. 2 (2003), 7-56. For an updated version of this work, see J. A. Belmonte "The Egyptian calendar: Keeping Ma' at on Earth", in In search of cosmic order, ed. by Belmonte and Shaltout (ref. 2), 75-132. L. Depuydt, Civil and lunar calendar in ancient Egypt (Orientalia Lovaniensia Analecta, 1xxvii; Leuven, 1997), A-S. von Bomhard, The Egyptian calendar: A work for eternity (London, 1999), and A. Spalinger, "Egyptian festival dating and the moon", in Under one sky, ed. by J. M. Steele and A. Imhausen (Münster, 2002), 379-404, are also relevant.

32. Belmonte, Shaltout and Fekri, op. cit. (ref. 2), 248-52.

33. Török, op. cit. (ref. 13), 318-19. For a detailed analysis of the temple of Kawa and its excavation, see M. F. Laming Macadam, The temples of Kawa II: History and archaeology of the site (London, 1955).

34. Interestingly, Sanam was excluded as a coronation pilgrimage temple since the time of King Harsiotef onwards (c. 400 B.c.), introducing the temple of Bastet of Tare instead. Rocheleau, op. cit. (ref. 13), 60 . 
35. Rocheleau, op. cit. (ref. 13), 76-77.

36. For a discussion on the topic, see Rocheleau, op. cit. (ref. 13), 77.

37. E. Krupp, "Light in the temples", in Records in stone: Papers in memory of Alexander Thom, ed. by C. L. N. Ruggles (Cambridge, 1988), 473-99. See also Belmonte, Shaltout and Fekri, op. cit. (ref. 2), 248-52.

38. R. Bradley, "Varia from the city of Meroe", Meroitica, vi (1982), 163-70. And see Török, op. cit. (ref. 13), 317 and 517.

39. Rocheleau, op. cit. (ref. 13), 80-81.

40. L. Török, "Meroitic architecture: Contributions to problems of chronology and style", Meroitica, vii (1984), 351-66.

41. See Papers 3 and 4.

42. Mohamed Ahmed and Anderson, op. cit. (ref. 17).

43. Rocheleau, op. cit. (ref. 13), 71.

44. Unless the temple was orientated during an earlier reign. For the alternative chronologies of Amanitore and Natakamani, see ref. 15.

45. Due to the mutual displacement between the Julian and the Gregorian calendars, this date is today $c$. September 11 Gregorian but it was still $c$. August 28 Gregorian for our period of interest, $c$. 10 B.C. to $c$. A.D. 50.

46. During the Ptolemaic period, the Zodiac was clearly accepted in Egypt, with Aries, the Ram constellation as the head of the zodiacal signs, signalling the spring equinox. See Lull and Belmonte, op. cit. (ref. 10, 2009). Actually, Mediterranean influence on star-lore had already arrived in the Kushite Kingdom during the Meroitic Period, for Petrie's excavations at Meroe uncovered a fragment of a zodiac (Petrie Museum, University College, UC43929) where the constellations - or signs - of Aquarius and Capricorn have been preserved. The Amun temple at Naga had the largest set of ram sphinxes in Sudan. We might speculate with the idea that the temple was orientated to the celestial ram, perhaps considered as an avatar of the god Amun. In this line of argument, see J. A. Belmonte, Las leyes del cielo (Madrid, 1999), 166-72. It is worth mentioning that this hypothesis would not fit for the temple of Tabo, built seven centuries earlier but still facing the equinoctial sun, rising on this occasion.

47. Rocheleau, op. cit. (ref. 13), 78.

48. See Rocheleau, op. cit. (ref. 13), for a discussion on the topic.

49. B. Zurawski, "Pliny's 'Tergedum' discovered", Sudan \& Nubia, ii (1998), 74-81. Rocheleau, op. cit. (ref. 13), 75, tentatively discusses an Amun ascription of the temple based on certain structural properties of the building.

50. Rocheleau, private communication.

51. Török, op. cit. (ref. 13), 305. The parallelism with Karnak and Luxor temples, also discussed by this author, is less evident; see Török, op. cit. (ref. 13), 184. This relationship would be, according to Török, reinforced by the orientation of Sanam temple to Temple B500 at Djebel Barkal, a proposal that is not correct.

52. Th. Kendall, "Les souverains de la montagne sacrée, Napata et la dynastie des Koushites", in Soudan, ed. by Wildung (ref. 17), 161-71 and note 78 .

53. In fact, from the southern extreme of the field of pyramids at Nuri, the northernmost border of Djebel Barkal is at $253 \frac{1}{2}^{\mathrm{lo}}$ which, for an angular horizon height of $1^{\circ}$, corresponds to a declination of $-15 \frac{10}{2}$. So Sirius did always set on the Pure Mountain as seen from a certain sector of Nuri, during the whole Kushite civilization.

54. The flowing of the Nile on site at $202^{\circ}$ (perpendicular at $112^{\circ}$ ) may also suggest a topographic connection but the actual orientations of Peye and Shabaka pyramid dromoi may suggest a Sirius relationship as well (declination of $-16^{\circ} .9$ c. 750 B.C.). The possibility of a site selection at El Kurru in order to obtain the double topographic and astronomical orientation could also be considered, taking into account what has been suggested for some of the Amun temples in the previous section. 
55. For a test of the quarter or inter-cardinal family, see Paper 4, Section 1.3. For an orientation of Egyptian pyramids to stars of Meskhetyu, see J. A. Belmonte, "On the orientation of the Old Kingdom pyramids", Archaeoastronomy, no. 26 (2001), S1-20, and K. Spence, "Ancient Egyptian chronology and the astronomical orientation of pyramids", Nature, cdviii (2000), 320-4.

56. Google Earth images have been combined with data obtained from general plans and azimuths published in Török, op. cit. (ref. 13), Edwards, op. cit. (ref. 15), Lehner, op. cit. (ref. 16), and J. N. Lockyer, The dawn of astronomy (New York, 1993). On-site, statistically-significant data would be highly desirable.

57. Sirius was not only the hypothetical main objective at El Kurru but also in Meroe North which has a maximum of the azimuth distribution centred at $107 \frac{1}{2}$. The maximum of the distribution at Nuri was of $130 \frac{1}{4}$, clearly suggesting an imitation of Taharqa's pyramid original orientation (see Table 3).

58. First Aktisanes (c. 315 B.C.) and later Aryamani (c. 300 B.C.) built their pyramids at Djebel Barkal (possibly Bar14 or 15 and Bar11, respectively). Török, op. cit. (ref. 13), 395. Arkamani(qo) was a contemporary of Ptolemy II (282-246 в.C.). Török, op. cit. (ref. 13), 442.

59. Török op. cit. (ref. 13), 395.

60. Interestingly, c. 350 в.C., an unknown Napatan king abandoned Nuri for El Kurru, building a royal pyramid (K1) on that spot. The experiment did not last. Török, op. cit. (ref. 13), 203.

61. See J. A. Belmonte, M. A. Molinero and N. Miranda, "Unveiling Seshat: New insights into the stretching of the cord ceremony", in In search of cosmic order, ed. by Belmonte and Shaltout (ref. 2), 195-212. The hypothesis defended in this essay suggests that the sign of Seshat (the divinity mostly involved in temple orientation ceremonies, notably the stretching of the cord), carried by the goddess upon her head in all representations, might perhaps have been a schematic and symbolic representation of an archaic transit instrument, similar to a Roman groma, that would have later become the hieroglyphic sign of the goddess. This instrument would have had eight radii and a viewpoint, and could have been used at the 'stretching of the cord' ceremonies since the dawn of Egyptian history, directly offering the eight directions under discussion from a single astronomical or topographical observation.

62. Such as the temples at Mons Porphyrites, Sikait, Nugrus, Bir Abu Safa, Ka'b Martu and Berenike. See S. E. Sidebotham, M. Hense and H. M. Nouwens, The Red Lands: The illustrated archaeology of Egypt's Eastern Desert (Cairo, 2008). Very recently, a series of temples have also being excavated in the Sinai at the site of Qantara Sharq.

63. Most of these results are based on high-resolution Google Earth images. Consequently, although field measurements in Sudan (especially of the horizon angular height) are highly desirable and will be welcome, we are certain that our general conclusions will not be severely affected by the new data. 
